\title{
LOCALITIES AND SITES OF PULSATILLA VERNALIS IN THE JULIAN ALPS
}

\author{
Igor DAKSKOBLER*, \\ Iztok SINJUR**, Ivan VEBER*** \& Branko ZUPAN****
}

\begin{abstract}
Applying the standard Central-European method we phytosociologically studied the sites of Pulsatilla vernalis, a rare and protected species of Slovenian flora, in the frost hollows on mountain pastures Ovčarija and Za Grivo in the Fužina pasturelands (the Triglav mountains, the Julian Alps). We established that it grows in a unique community of swards and heaths which usually extends over small surfaces $\left(4-10 \mathrm{~m}^{2}\right)$ and is dominated by herbaceous perennial species (hemicryptophytes) and dwarf shrubs (chamaephytes) with mostly arcticalpine and south-European montane distribution. This community is explicitly (floristically and ecologically) different from the communities of swards and heaths described in the Julian Alps so far, so we classified it into a new association Pulsatillo vernalis-Dryadetum octopetalae ass. nova (order Rhododendro hirsuti-Ericetalia carneae) and subdivided it into two, floristically and ecologically clearly distinguished subassociations -ericetosum carneae subass. nova and -vaccinietosum subass. nova.

Key words: Pulsatilla vernalis, Rhododendro hirsuti-Ericetalia carneae, phytosociology, syntaxonomy, frost hollows, the Fužina pasturelands (Fužinske planine), the Julian Alps, Slovenia.

\section{Izvleček}

Po standardni srednjeevropski metodi smo v mraziščnih kotanjah na pl. Ovčarija in Za Grivo v Fužinskih planinah (Triglavsko pogorje, Julijske Alpe) fitocenološko preučili rastišča redke in zavarovane vrste slovenske flore, Pulsatilla vernalis. Ugotovili smo, da raste v svojevrstni, navadno na majhnih površinah (4-10 $\left.\mathrm{m}^{2}\right)$ razširjeni združbi rušnatih trav in resav, v kateri prevladujejo zelnate trajnice (hemikriptofiti) ter polgrmi in nizki grmiči (hamefiti) predvsem z arktično-alpinsko in južnoevropsko gorsko razširjenostjo. Ker se ta združba floristično in ekološko očitno razlikuje od doslej v Julijskih Alpah opisanih združb rušnatih trav in resav, jo uvrščamo v novo asociacijo Pulsatillo vernalis-Dryadetum octopetalae ass. nova (red Rhododendro hirsuti-Ericetalia carneae) in jo členimo na dve floristično in ekološko dobro prepoznavni subasociaciji -ericetosum carneae subass. nova in -vaccinietosum subass. nova.
\end{abstract}

Ključne besede: Pulsatilla vernalis, Rhododendro hirsuti-Ericetalia carneae, fitocenologija, sintaksonomija, mrazišča, Fužinske planine, Julijske Alpe, Slovenija.

\section{INTRODUCTION}

Pulsatilla vernalis is an arctic-alpine or European montane species (Pignatti 1982: 298, Poldini 1991: 621, Aeschimann \& al. 2004 a: 148) of subalpine and alpine basophile and acidophile swards (Pignatti, ibid.) or (according to Oberdorfer 1983: 403 and Adler \& al. 1994: 275) species of dry grasslands (»Magerrasen «) on silicate bedrock and acid soil in the (subalpine)-alpine belt, very rarely also in the submontane and montane belt, where it grows also in Scots pine heaths. The species is most frequently found on moderately fresh and base-rich, as well as more or less acid, humose loamy soil (Oberdor-

\footnotetext{
* Institute of Biology, Scientific Research Centre of the Slovenian Acadamy of Sciences and Arts, Regional unit Tolmin, Brunov drevored 13, SI-5220 Tolmin, Igor.Dakskobler@guest.arnes.si

** Slovenian Forestry Institute, Večna pot 2, SI-1000 Ljubljana, iztok.sinjur@gozdis.si

*** Zoisova 24, SI-4264 Bohinjska Bistrica

**** Savica 6, SI-4264 Bohinjska Bistrica
} 
fer, ibid.). Aeschimann \& al. (ibid.) find that it grows on calcareous, calcareous-silicate and silicate geological bedrock, on acid to neutral soil which is nutrient- (nitrogen) poor and not very well supplied with water (medium dry), mostly in the subalpine and alpine belt. It is a character species of subalpine-alpine swards on acid soil of the Centraland South-European mountain ranges from the class Juncetea trifidi Hadač 1946 (= Caricetea curvulae Braun-Blanquet 1948) - Aeschimann \& al. (ibid.) and order Caricetalia curvulae $\mathrm{Br}$.-Bl. in Br.-Bl. \& Jenny 1926 (Grabherr 1993 a: 345). Within the territory of former Yugoslavia, Trinajstić (1973: 288) mentions it for Montenegro (Kom planina) and for Serbia. According to Lakušić (2008, in litt.) and Vukojičić (2008, her data is based on revision of herbarium collections of public Herbaria BEOU and BEO as well as on many publications from this territory, for example Rohlena 1942, Micevski 1979, 1985, Nikolić \& al. 1986, Diklić 1992, Krivošej \& Ranđelović 1996, Amidžić \& Panjković 2003 and Niketić \& al. 2007) the localities of Pulsatilla vernalis in Serbia (Kosovo) are in the Prokletije mountains (Đeravica, Derviš Kom, Kurvala), in Montene- gro in the Komovi mountains and in the Republic of Macedonia in the Šar planina (Rudoka-Popova Šapka) and Jablanica mountains (Crni kamen). It grows there at the altitudes between 1700 to 2650 $\mathrm{m}$ on carbonate and silicate bedrock, in dwarf shrub communities of the alliance Juniperion nanae (= Juniperion sibiricae), in rock-crevice communities of the class Asplenietea trichomanis and in the alpine grasslands of the orders Onobrychido-Seslerietalia (on calcareous bedrock) and Seslerietalia comosae (on silicate bedrock) - Vukojičić (ibid.).

Acidophilous high-mountain swards from the class Juncetea trifidi are rather rare in the Slovenian Alps (mostly because of the prevailing calcareous bedrock) and still insufficiently researched (the results of the research conducted by T. Wraber, partly together with B. Surina, have been published only fragmentarily - T. Wraber 1969, 1983, 1984). The largest surfaces covered by these swards are in the vicinity of Mangrt. T. Wraber (1996: 110) mentions several floristic rarities within them, among which are Helictotrichon versicolor, Juncus trifidus, Carex curvula and Pulsatilla alba (= P. alpina subsp. alba), but not Pulsatilla vernalis, which had been unknown in

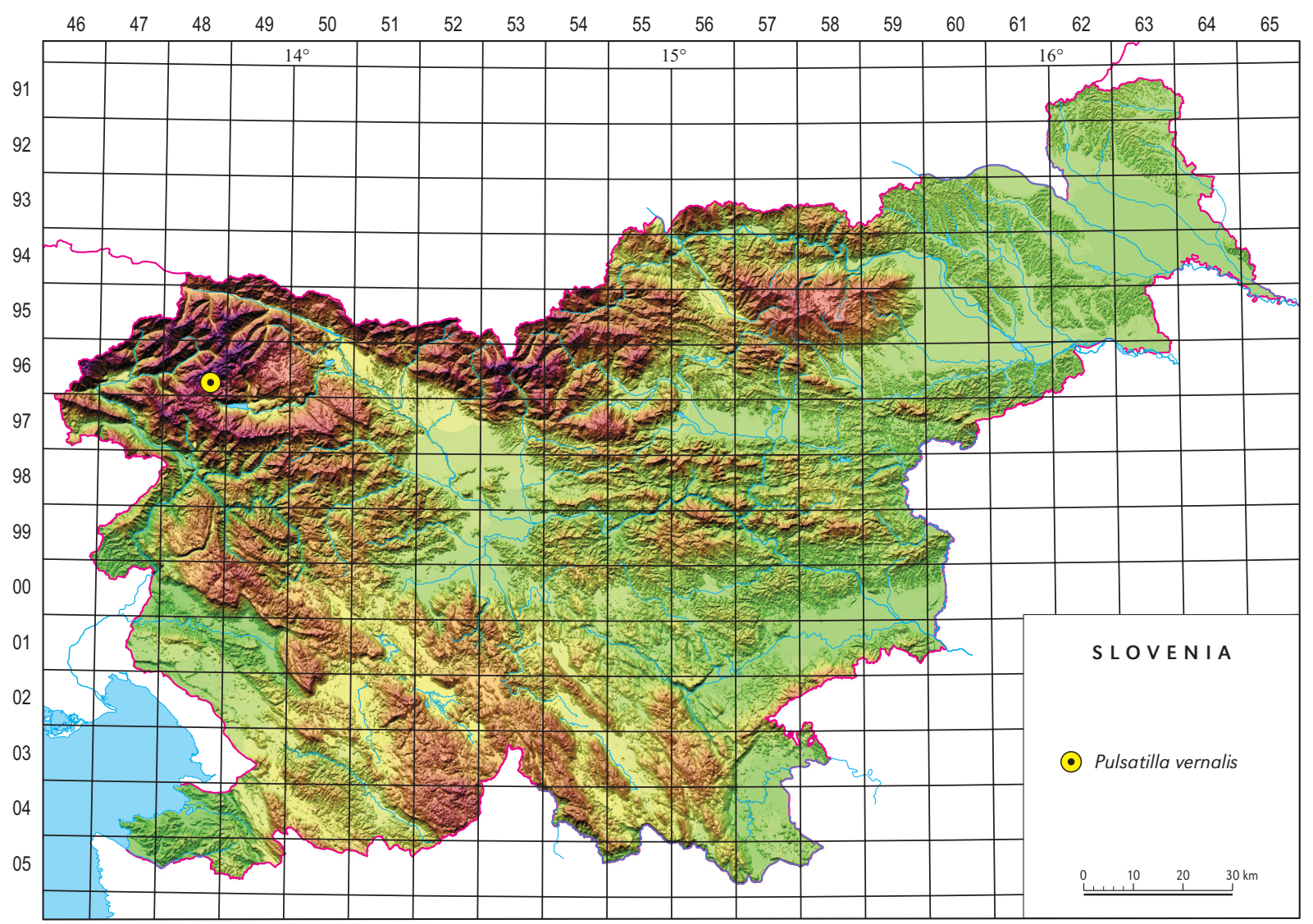

Figure 1: Distribution of Pulsatilla vernalis in Slovenia.

Slika 1: Razširjenost vrste Pulsatilla vernalis v Sloveniji. 
Slovenia until a few years ago. In the neighbouring Carinthia in Austria it is distributed above all in the northern and northwestern part of the country, but its localities along the border with Slovenia are not known (Hartl \& al. 1992: 291). Even in Friuli the localities are in the northern part of the country, mostly on the border with Austria, but not in the Western Julian Alps (Poldini 2002: 395). Poldini (2008, in litt.) noticed Pulsatilla vernalis on silicate sites in the Carnian Alps, within the stands of the association Sieversio-Nardetum.

The unusual hairy plant with purple flowers (Pulsatilla sp.) was first noticed in the Julian Alps, on the southwestern part of the Bohinj mountain pasture Ovčarija in 2002 by the photographer Marko Pogačnik. He informed Ivan Veber about his find and in the following years the latter examined the locality and the plant in flowering and fructifying stage several times. Peter Skoberne helped him to determine it as a species new to the Slovenia floraPulsatilla vernalis (Veber 2006). Veber's publication is already included in the last edition of the Mala flora Slovenije (T. Wraber 2007: 133-134) and its distribution map in Slovenia was made on this basis (Figure 1). In the spring and summer of 2007 we closely examined the localities of this vernal plant on the mountain pasture Ovčarija. We found a new locality in a frost hollow Za Grivo (at the altitude of 1635-1650 m, near the path between the mountain pastures Viševnik and Ovčarija) and recorded its stands (Figure 2). Our findings are summed up in this paper.

\section{METHODS}

The air temperature in the dolines (pits) on pastures Ovčarija and Za Grivo in the period from October 2006 to September 2007 was measured by an automatic temperature recorder "thermo button" or "i-button" (button-shaped thermometer) with the time interval of 15 minutes. The provider is Dallas Semiconductor. The recorder was placed in a special, home-made shelter which protected it from the unfavourable weather conditions (rainfall) and albedo. The air temperature data on the official meteorological station Vogel were provided by the Meteorological Office of the Environmental Agency of the Republic of Slovenia (ARSO). The vegetation on the localities of Pulsatilla vernalis was recorded applying the standard Central-European method (Braun-Blanquet 1964). The collected relevés were entered into the FloVegSi database

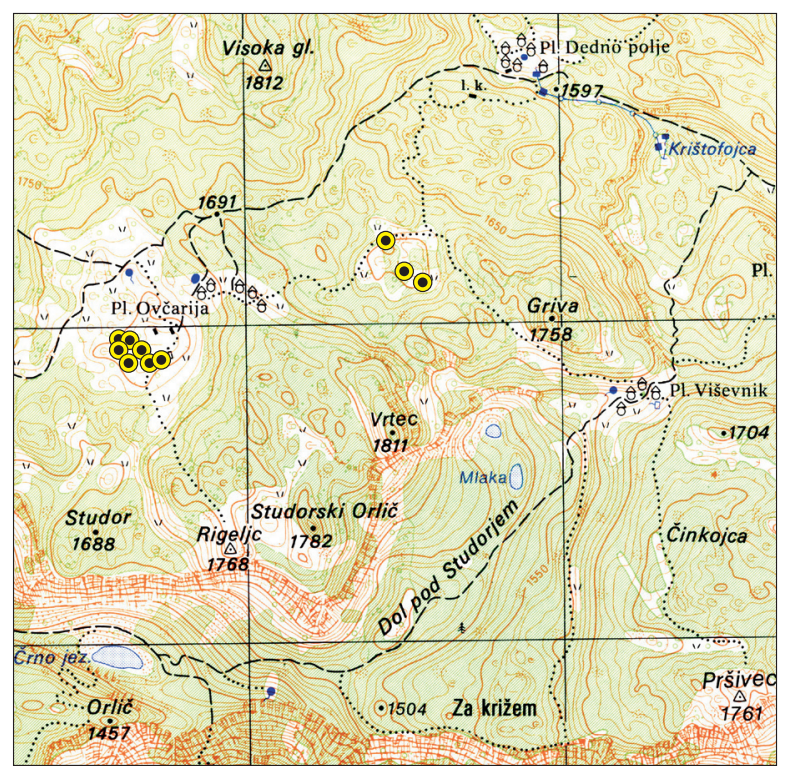

Figure 2: Localities of Pulsatilla vernalis on the pasture Ovčarija and Za Grivo (Source: State topographical map $1: 25$ 000, GURS).

Slika 2: Nahajališča vrste Pulsatilla vernalis na pl. Ovčarija in Za Grivo. (Vir: Državna topografska karta RS 1 : 25 000, GURS).

(T. Seliškar \& al. 2003) and then compared applying the methods of hierarchical classification and Principal Coordinates Analysis (PCoA). We used the SYN-TAX program package (Podani 2001). The combined cover-abundance values were transformed into the ordinal scale as proposed by van der Maarel (1979). When conducting our comparisons the following methods of hierarchical clustering were used: »complete linkage (farthest neighbour) method - FNC«, »(Unweighted) average linkage method - UPGMA«, »(Weighted) average linkage method - WPGMA«, »Incremental sum of squares - MISSQ " and the Principal Coordinates Analysis (PCoA) ordination method. The similarity measures were the Sørensen and Jaccard indexes (when only presence or absence of species was considered) and Wishart's coefficient (similarity ratio). On the basis of these comparisons a phytosociological table was made (Table 1 ), in which we calculated not only the presence and frequency for each taxon, but also its cover index $\left(I_{c}\right)$ - Lausi \& al. (1982: 124) and its share of coverage $\left(D_{\%}\right)-S u-$ rina (2004: 102, 2005: 15). The recorded species were arranged and analyzed according to Raunkiaer's life forms, chorological affinity (geoelemental composition) and phytosociological groups (groups of diagnostic species). Most of the listed 
data come from the Flora alpina (Aeschimann \& al. 2004 a,b,c).

The nomenclature source for the names of vascular plants is the Mala flora Slovenije (Martinčič \& al. 2007), Frahm \& Frey (1992) and Martinčič (2003) for the names of mosses, and Wirth (1995) for the names of lichens. We were unable to determine all of the moss and lichen species, so some of the analyses do not include the moss layer. For the names of the syntaxa we mainly follow Theurillat \& al. (1995), Theurillat in Aeschimann \& al. (2004 c), Grabherr (1993 a, b, c) and Surina (2005). All the syntaxonomical units in the paper and their authors are listed in the Appendix.

\section{ECOLOGICAL CHARACTERIZATION OF THE RESEARCH AREA}

The only localities of Pulsatilla vernalis in Slovenia known so far are in the Fužina pasturelands - Fužinske planine (the Julian Alps, the Triglav mountains, Figures 1 and 2). Fužinske planine are the common name for the region between the valley of Voje and Velo polje in the east and the Triglav Lakes Valley in the west, which belongs to the pasture community Studor-Stara Fužina (Mihelič 1992: 130-134, Novak 1985: 148; Cevc 1992: 39- 42, Melik 1950: 179-180). The pasture Ovčarija is a vast and elongated mountain pasture that occupies a large part of the western fringes of the Fužinske planine. It is one of the highest $(1660 \mathrm{~m})$ and remotest mountain pastures in our Alps (Mihelič, ibid.). The geological bedrock is massive Triassic limestone (Buser 1986: 40-41, 1987) and the overall climate of the Fužinske planine is montane (Ogrin 1996: 46-47). It can be loosely described with the climate data for the meteorological observatory Dom na Komni (1520 m) - Mekinda-Majaron (1995: 41), B. Zupančič (1995: 46). The mean annual temperature here in the period between 1961-1990 was $3,7^{\circ} \mathrm{C}$ (interpolated value), the mean temperature of the warmest month in July in the same period was $12,4^{\circ} \mathrm{C}$, the vegetation period with the mean monthly temperature of above $5{ }^{\circ} \mathrm{C}$ lasted from May to October (about five months). The mean temperature of the coldest months was $-4{ }^{\circ} \mathrm{C}$ (January, February). In the same period (1961-1990), an average of $2934 \mathrm{~mm}$ of precipitation evenly distributed across the year was measured on Komna, with the highest average in April $(283 \mathrm{~mm})$ and November $(395 \mathrm{~mm})$, in the cold period from November to March mostly as snow. On Vogel
(1535 m), in the period between 1981-1990, there was on average even a little more precipitation (3077 $\mathrm{mm})$, also with a high in November $(395 \mathrm{~mm})-\mathrm{B}$. Zupančič (1996: 337). However, the values for the temperature conditions and precipitation quantity on meteorological observatories Dom na Komni and Vogel are only approximate indicators of the local climate on the mountain pastures Ovčarija and Za Grivo, mostly because of their distance from the ridge of the Bohinj-Tolmin mountains (the Lower Bohinj mountains), where the precipitation is more common because of the orographic effects and morphological characteristics of the localities' surroundings. The pasture Ovčarija is situated in a 'konta' (a larger Karstic depression or doline with the diameter of several hundred metres - Kunaver 1985: 55), similarly to the doline (konta) Za Grivo. Both these locations are frost hollows, which means that on clear tranquil nights the temperatures there are often considerably lower than in the vicinity (Martinčič 1977: 231, Ogrin \& al. 2007: 198). The temperature conditions in both dolines are therefore significantly different from those on the plateuas of Komna and Vogel. This was confirmed also by the measurements of the researchers from the Slovenian meteorological forum. They had set up instruments for measuring air temperature in these two frost hollows (frost hollow of the pasture Ovčarija and frost hollow Vrtec or the hollow $\mathrm{Za}$ Grivo, which lies to the north under Mt. Vrtec, $1811 \mathrm{~m})$ - Sinjur \& al. (2007). Based on the air temperature measurements on pastures Ovčarija and $\mathrm{Za}$ Grivo it was established that both localities of Pulsatilla vernalis known in the Julian Alps so far have very harsh growth conditions, mostly because

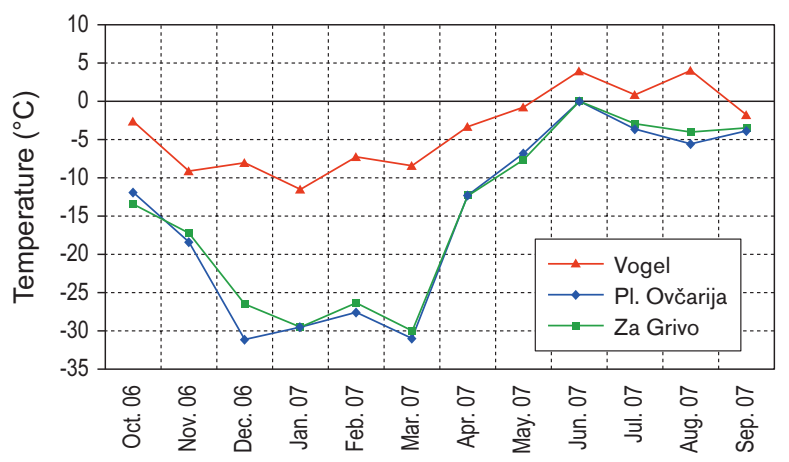

Figure 3: The lowest temperature by months on Vogel $(1535 \mathrm{~m})$ and in dolines (pits) of the pastures Ovčarija and Za Grivo.

Figure 3: Najnižja temperatura po mesecih na Voglu (1535 m) in v kontah na pl. Ovčarija in Za Grivo. 
of the low morning temperatures (that can be as low as $-30{ }^{\circ} \mathrm{C}$ or less in the winter - Sinjur \& Ogrin 2006, and which relatively often stay a few degrees Celsius below zero even during the calendar summer) - Figure 3.

The localities of Pulsatilla vernalis on the pasture Ovčarija are on the south and southwestern rim of the doline (Fig. 2) and are only slightly elevated above its lowest point (where the measuring instruments are), i.e. definitely still in the cold air belt. The localities of the vernal hairy plant in the hollow Za Grivo are mostly also very near the lowest point of the doline (to the south of the doline, with the exception of one locality which is to the north of this gauging station, near the mountain path towards the pasture Ovčarija). Presumably, these are the potential sites of an Alpine dwarf pine community on calcareous bedrock (Rhododendro hirsuti-Pinetum prostratae) that was cleared out in the past in order to extend pastures. The forest had probably been overgrowing only the higher-lying slopes on the rims of both dolines. The current open larch stands on the slopes south of the pasture Ovčarija and doline Za Grivo are mostly classified into the syntaxon Rhodothamno-Laricetum. The slopes might once have been overgrown also with the subalpine spruce forest (Adenostylo glabrae-Piceetum sensu Zupančič 1999 or Homogyno sylvestris-Piceetum sensu Exner 2006 and Poldini \& Bressan 2007).

The soil under the swards of perennial herbs, dwarfs and (semi)bushes overgrowing the rims of the dolines on the pasture Ovčarija and Za Grivo are organogenic rendzinas (folic leptosols - WRB, 2006), whose characteristic feature is raw humus (Mor) - Urbančič \& al. (2005: 9-10, 2008, in litt., Table 6). Organogenic rendzinas occur above all in very cold, humid conditions in the high-mountains and frost hollows, where the decomposition of organic matter is slow. This is similar to peat soil, for example, which develops upwards with accumulation of raw humus. The leaching of base cations can make the soil very acid, poorly fertile and for the most part overgrown with acidophilous and "piceetal" vegetation (Urbančič \& al., ibid.). In our case, the slow decomposition of organic matter is related above all to the cold expositions and less so to the altitude.

\section{RESULTS AND DISCUSSION}

Table 1 comprises 14 relevés of the stands with Pulsatilla vernalis on the pastures Ovčarija and $\mathrm{Za}$ Grivo, arranged with hierarhical classification. On average 34 species were found, standard deviation was 4 and coefficient of variation $11 \%$. Biological spectrum analysis, in which mosses and lichens were not considered, gave the following results (Table 2).

Table 2: Plant life forms spectrum of the stands with Pulsatilla vernalis on the pasture Ovčarija and Za Grivo (relative frequencies). Fr. - Frequency; $I_{c}-$ Cover index; $\mathrm{D}_{\%}$ - Share of coverage.

Tabela 2: Spekter življenjskih oblik v sestojih z vrsto Pulsatilla vernalis na pl. Ovčarija in Za Grivo (relativne frekvence). Fr. - frekvenca; $I_{c}$ - indeks pokrovnosti; $\mathrm{D}_{\%}$ - delež pokrovnosti.

\begin{tabular}{lrrrrr}
\hline Weight (Utež) & & & Fr. & $\mathrm{I}_{\mathrm{c}}$ & $\mathrm{D}_{\%}$ \\
\hline Phanerophytes (Fanerofiti) & $\mathrm{P}$ & 3.6 & 2.9 & 2.1 & 2.1 \\
Chamaephytes (Hamefiti) & $\mathrm{Ch}$ & $\mathbf{2 1}$ & $\mathbf{2 6}$ & $\mathbf{3 5}$ & $\mathbf{3 5}$ \\
Hemicryptophytes (Hemikriptofiti) & $\mathrm{H}$ & $\mathbf{7 0}$ & $\mathbf{6 8}$ & $\mathbf{6 0}$ & $\mathbf{6 0}$ \\
Geophytes (Geofiti) & $\mathrm{G}$ & 2.4 & 2.9 & 2.6 & 2.6 \\
Therophytes Terofiti) & $\mathrm{T}$ & 2.4 & 0.4 & 0.3 & 0.3 \\
\hline Total (Skupaj) & & 100 & 100 & 100 & 100 \\
\hline
\end{tabular}

If the species are given equal consideration regardless of their frequency, the prevailing species are herbaceous perennials, hemicryptophytes (70\%), followed by semi-bushes, dwarf shrubs and perennial swards (chamaephytes) - altogether $21 \%$. Other life forms, phanerophytes (trees and shrubs), geophytes and therophytes (annual plants) are represented with only a few species within the stands studied. If we use species frequency as weight, the proportion of chamaephytes increases $(26 \%)$, while the proportion of other groups decreases. If weight is cover index or share of coverage, the proportion of chamaephytes increases to $35 \%$ and the proportion of hemicryptophytes is $60 \%$. A high proportion of chamaephytes in the studied community undoubtedly indicates very harsh life conditions for its growth. Such a high proportion of chamaephytes (about 20\% and more) is characteristic only for deserts, the arctic and highmountain (alpine) belt (Stefanović 1986: 29).

Analysis according to chorological affinity is presented in Table 3. Considering only the presence of species, regardless of their frequency and abundance, the prevailing species are the South-European montane species $(31 \%)$ and arctic-alpine species $(17 \%)$. A similar proportion is obtained if weight is frequency of species. If cover index is considered, the proportion of arctic-alpine species slightly increases $(19 \%)$, while the proportion of 
South-European montane species slightly decreases $(28 \%)$. This analysis also indicates extreme life conditions that mostly arctic-alpine and montane species can handle.

Table 3: Chorological groups in the stands with Pulsatilla vernalis on the pasture Ovčarija and $\mathrm{Za}$ Grivo (relative frequencies). Fr. - Frequency; $\mathrm{I}_{c}-$ Cover index; $\mathrm{D}_{\%}$ - Share of coverage.

Tabela 3: Horološke skupine v sestojih z vrsto Pulsatilla vernalis na pl. Ovčarija in Za Grivo (relativne frekvence). Fr. - frekvenca; $I_{c}$ - indeks pokrovnosti; $\mathrm{D}_{\%}-$ delež pokrovnosti.

\begin{tabular}{|c|c|c|c|c|}
\hline Wels & & Fr. & $\mathrm{I}_{\mathrm{c}}$ & $\mathrm{D}_{\%}$ \\
\hline $\begin{array}{l}\text { Alpine and Alpine-Carpathian species } \\
\text { (Alpske in alpsko-karpatske vrste) }\end{array}$ & 2.4 & 2 & 3.3 & 3.3 \\
\hline $\begin{array}{l}\text { Arctic-alpine species (Arktično- } \\
\text { alpinske vrste) }\end{array}$ & 17 & 15.7 & 19 & 19 \\
\hline (Vobodnolnclo & 4.8 & 5.9 & 5.7 & 5.8 \\
\hline (Vzh & 6 & 7 & 5.9 & 5.9 \\
\hline arop & 9.5 & 14 & 12.8 & 13 \\
\hline ske & 4.8 & 4.1 & 4.8 & 4.9 \\
\hline montane species & 8.3 & 6.3 & 4.7 & 4.4 \\
\hline $\begin{array}{l}\text { S-European montane species } \\
\text { (Južnoevropske gorske vrste) }\end{array}$ & 31 & 28.7 & 28 & 28 \\
\hline $\begin{aligned} \text { Eurc } \\
(\mathrm{El}\end{aligned}$ & 6 & 4.8 & 3.9 & \\
\hline $\begin{array}{l}\text { Eurosiberian-N-American species } \\
\text { (Evrosibersko-severnoameriške vrs }\end{array}$ & 11 & 11.5 & 11.9 & 12 \\
\hline otal (Skupaj) & 100 & 100 & 100 & 10 \\
\hline
\end{tabular}

The highest proportion in the studied community, regardless of whether they are given equal consideration or whether we take into consideration also their frequency and abundance, have the species of subalpine-alpine grasslands and swards on calcareous bedrock (i.e. the species from the alliances Caricion firmae and Caricion austroalpinae, order Seslerietalia variae and class Elyno-Seslerietea, species of the alliance Oxytropido-Elynion are treated separately). Their total proportion is about $50 \%$ (considering the presence and frequency of species) or $44 \%$ (if cover index and share of coverage are used as the weight). After these calculations the studied community should definitely be classified into the class Elyno-Seslerietea. The species of the order Rhododendro hirsuti-Ericetalia carneae Grabherr, Greimler \& Mucina 1993, which comprises Alpine
Table 4: Phytosociological groups (= groups of diagnostic species) in the stands with Pulsatilla vernalis on the pasture Ovčarija and $\mathrm{Za}$ Grivo (relative frequencies). Fr. - Frequency; $I_{c}$ - Cover index; $D_{\%}$ - Share of coverage.

Tabela 4: Sestava po skupinah diagnostičnih vrst $\mathrm{v}$ sestojih $\mathrm{z}$ vrsto Pulsatilla vernalis na pl. Ovčarija in $\mathrm{Za}$ Grivo (relativne frekvence). Fr. - frekvenca; $\mathrm{I}_{c}$ - indeks pokrovnosti; $D_{\%}$ - delež pokrovnosti.

\begin{tabular}{lrrrr}
\hline Weight (Utež) & & Fr. & $\mathrm{I}_{\mathrm{c}}$ & $\mathrm{D}_{\%}$ \\
\hline Rhododendro hirsuti-Ericetalia carneae & $\mathbf{7 . 1}$ & $\mathbf{9 . 3}$ & $\mathbf{1 2}$ & $\mathbf{1 2}$ \\
Caricion firmae & 4.8 & 3.7 & 2.8 & 2.8 \\
Caricion austroalpinae & 6 & 6.5 & 4.8 & 4.8 \\
Seslerietalia variae & $\mathbf{1 7}$ & $\mathbf{1 1}$ & $\mathbf{9 . 4}$ & $\mathbf{9 . 5}$ \\
Elyno-Seslerietea & $\mathbf{2 4}$ & $\mathbf{3 0}$ & $\mathbf{2 7}$ & $\mathbf{2 7}$ \\
Juncetea trifidi & 11 & $\mathbf{1 2}$ & $\mathbf{1 2}$ & $\mathbf{1 1 . 9}$ \\
Calluno-Ulicetea & 3.6 & 1.7 & 1.4 & 1.4 \\
Oxytropido-Elynion & 6 & 4.8 & $\mathbf{8 . 4}$ & $\mathbf{8 . 5}$ \\
Leuseleurio-Vaccinietea & 1.2 & 2.2 & 3.4 & 3.4 \\
Caricetalia davallianae & 3.6 & 3 & 2.8 & 2.8 \\
Arabidetalia caeruleae & $\mathbf{7 . 1}$ & $\mathbf{6 . 5}$ & 5.9 & 5.9 \\
Mulgedio-Aconitetea & 1.2 & 0.2 & 0.2 & 0.2 \\
Molinio-Arrhenatheretea & 3.6 & 4.6 & 3.6 & 3.6 \\
Vaccinio-Piceetea & 4.8 & 4.6 & $\mathbf{6 . 2}$ & $\mathbf{6 . 2}$ \\
\hline Total (Skupaj) & 100 & 100 & 100 & 100 \\
\hline
\end{tabular}

(montane) heaths on calcareous bedrock (Grabherr \& al. 1993: 434), were treated separately. These are mostly pioneer communities on dolomite and limestone bedrock, on coarse rubble, on collapse blocks, in alpine karst with karrens. Diagnostic (character and differential) species of this order are Daphne striata, Genista radiata, Rhodothamnus chamaecistus, Erica carnea, Juniperus alpina, Rhododendron hirsutum, Pinus mugo etc. Its authors classify it into the class Elyno-Seslerietea (Grabherr \& al., ibid.). Theurillat (in Aeschimann \& al. 2004 c: 310) classifies the order Rhododendro hirsuti-Ericetalia carneae Grabherr, Greimler \& Mucina and Grabherr \& Mucina 1993 into the class Loiseleurio-Vaccinietea Eggler ex Schubert 1948, which comprises the communities of subalpine-alpine heaths - Theurillat \& al. (1995: 224), or heaths from the Arctic regions and mountains of boreal and nemoral belt - Grabherr (1993 c: 447). Among the diagnostic species of this class is Vaccinium gaultherioides (Grabherr 1993 c, ibid.), which occurs also in our relevés. The total proportion of the species of arctic-alpine heaths in our relevés is about $8 \%$ (when given equal consideration) or $12 \%$ (considering their frequency) and $15,5 \%$ (considering also medium coverage, 
cover index). The species characteristic for heaths on calcareous bedrock prevail.

Species of subalpine-alpine swards on acid soil (class Juncetea trifidae $=$ Caricetea curvulae) also have a significant proportion (11 or $12 \%$ ) in the studied community. Common species from this diagnostic group in our relevés, apart from Pulsatilla vernalis, are also Festuca nigrescens, Campanula scheuchzeri and Potentilla aurea. Other more acidophilous species that grow in the studied community are classified into the classes Calluno-Ulicetea and Vaccinio-Piceetea (in our relevés, Vaccinium vitis-idaea, which is differential also for the communities of acidophilous heaths, is the most constant and abundant species among those diagnostic for this class). Diagnostic species from the alliance Oxytropido-Elynion (according to Grabherr 1993 and Theurillat in Aeschimann \& al. $2004 \mathrm{c}$ this alliance is classified into the class Carici rupestris-Kobresietea bellardii, while according to Oriolo 2001 classification within the class Elyno-Seslerietea is more proper), which comprises the communities of naked-rush swards with Elyna myosuroides, also indicate the characteristics of the studied community with their proportion ( 5 to $8 \%$, depending on the weight). These species occur only on special sites in the Central- and South-European mountain ranges (above all on wind-exposed ridges, on edges with low snow cover, on base and weakly acid soil). They therefore occur extrazonally and are in contact with the grasslands from the classes Caricetea curvulae (= Juncetea trifidi) and Elyno-Seslerietea (Grabherr 1993 b: 373). The diagnostic species of the alliance Oxytropido-Elynion which occur in the studied community are mostly Dryas octopetala, Antennaria carpatica and Carex rupestris, possibly also Carex capillaris and C. atrata, although these two sedges are diagnostic also for the snow-bed communities from the order Arabidetalia caeruleae (class Thlaspietea rotundifolii). Within the studied community, the most frequent among the species from this order are Homogyne discolor and Soldanella alpina, which indicate that the snow on these sites keeps rather long into the spring.

Analysis of sociological groups shows a unique plant community with elements of different associations, alliances and even classes. According to our findings, the reasons for their collective growth are sites in frost hollows (frost exposed aspects) with long snow cover periods, slow decomposition of organic matter and raw, acid humus. The species with the highest cover index in the studied community $\left(I_{c}=67\right)$ and the highest share of coverage $\left(\mathrm{D}_{\%}=6,9 \%\right)$ is Dryas octopetala, followed by
Vaccinium vitis-idaea $\left(\mathrm{I}_{\mathrm{c}}=44, \mathrm{D}_{\%}=4,6\right)$ and Pulsatilla vernalis $\left(\mathrm{I}_{\mathrm{C}}=39, \mathrm{D}_{\%}=4\right)$. The most thoroughly studied in the Julian Alps are the subalpine-alpine plant communities in the Krn mountains (Surina 2005). Among the Fužinske planine and the Krn mountains is a large plateau of Komna. Nevertheless, these regions are still geographically and ecologically very similar. Among the communities described in the Krn mountains by Surina (ibid.), the stands which are the most similar to the studied stands are those from the associations Dryadetum octopetalae Rübel 1911 (cover index and share of coverage of Dryas octopetala are considerably higher here, $\left.\mathrm{I}_{\mathrm{c}}=98, \mathrm{D}_{\%}=19,9\right)$, Rhododendretum hirsuti Lüdi 1921 and Empetro-Vaccinietum gaultherioidis Br.-Bl. in Br.-Bl. \& Jenny 1926 corr. Grabherr 1993. We made a synthetic table (Table 5 ) and compared all four syntaxa (Figures 4-7).

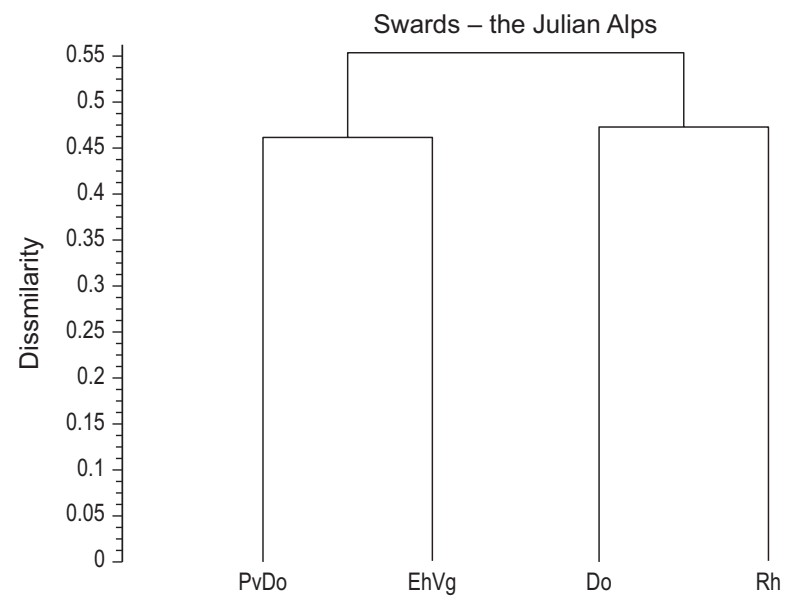

Figure 4: Dendrogram of subalpine-alpine swards and heaths (PvDo - Pulsatillo vernalis-Dryadetum, Do - Dryadetum octopetalae, Rh - Rhododendretum hirsuti, EhVg - Empetro-Vaccinietum gaultherioidis) - UPGMA, the Sørensen index.

Slika 4: Dendrogram subalpinsko-alpinskih rušnatih trat in resav (PvDo - Pulsatillo vernalis-Dryadetum, Do - Dryadetum octopetalae, Rh - Rhododendretum hirsuti, EhVg - Empetro-Vaccinietum gaultherioidis) - UPGMA, Sørensenov količnik.

Considering only the presence and absence of species, the association Empetro-Vaccinietum gaultherioidis is the most similar to the studied community, but the coefficient of floristic similarity according to Sørensen is only about $54 \%$ (Figure 4) and $38 \%$ according to Jaccard (Figure 5). However, if we take into consideration also the frequency of species, our relevés become more similar to the stands of the association Rhododendretum hirsuti (Figure 6). 


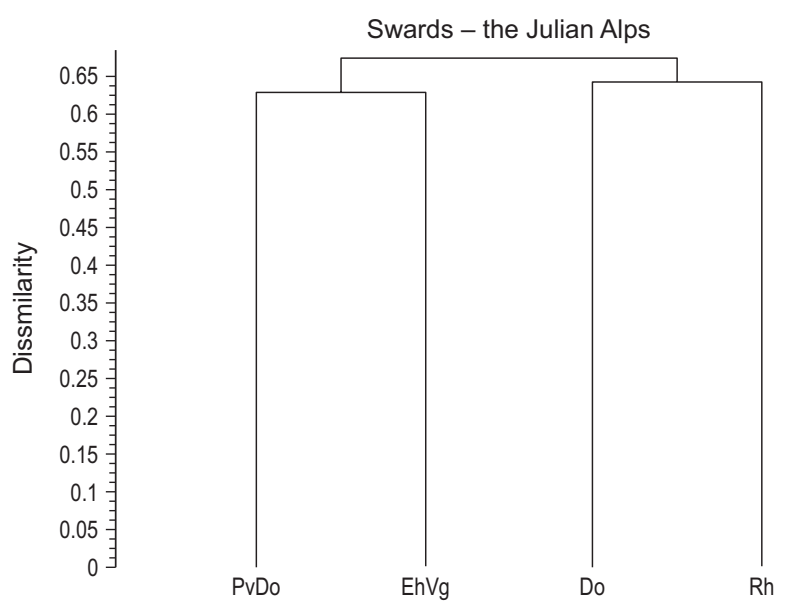

Figure 5: Dendrogram of subalpine-alpine swards and heaths (PvDo - Pulsatillo vernalis-Dryadetum, Do - Dryadetum octopetalae, Rh - Rhododendretum hirsuti, EhVg - EmpetroVaccinietum gaultherioidis) - UPGMA, the Jaccard index.

Slika 5: Dendrogram subalpinsko-alpinskih rušnatih trat in resav (PvDo - Pulsatillo vernalis-Dryadetum, Do - Dryadetum octopetalae, Rh - Rhododendretum hirsuti, EhVg - Empetro-Vaccinietum gaultherioidis) - UPGMA, Jaccardov količnik.
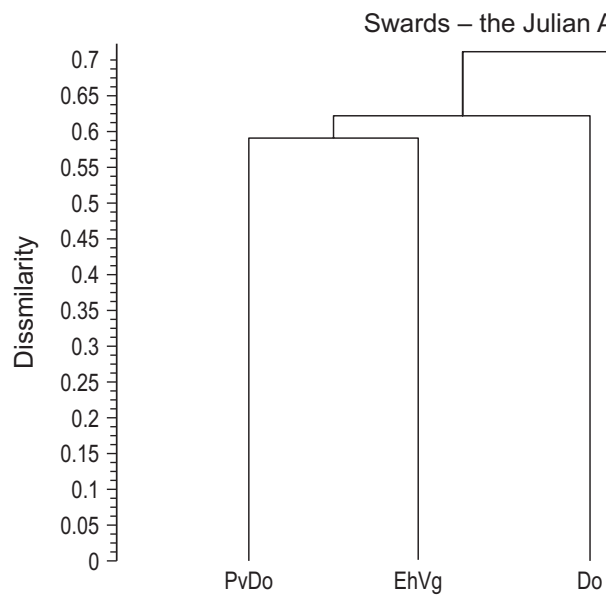

Figure 6: Dendrogram of subalpine-alpine swards and heaths (PvDo - Pulsatillo vernalis-Dryadetum, Do - Dryadetum octopetalae, $\mathrm{Rh}$ - Rhododendretum hirsuti, EhVg - Empetro-Vaccinietum gaultherioidis) - UPGMA, similarity ratio.

Slika 6: Dendrogram subalpinsko-alpinskih rušnatih trat in resav (PvDo - Pulsatillo vernalis-Dryadetum, Do - Dryadetum octopetalae, Rh - Rhododendretum hirsuti, EhVg - Empetro-Vaccinietum gaultherioidis) - UPGMA, similarity ratio.

The two-dimensional scatter diagram (Figure 7) clearly shows that four different communities were compared. Based on these comparisons, the stands

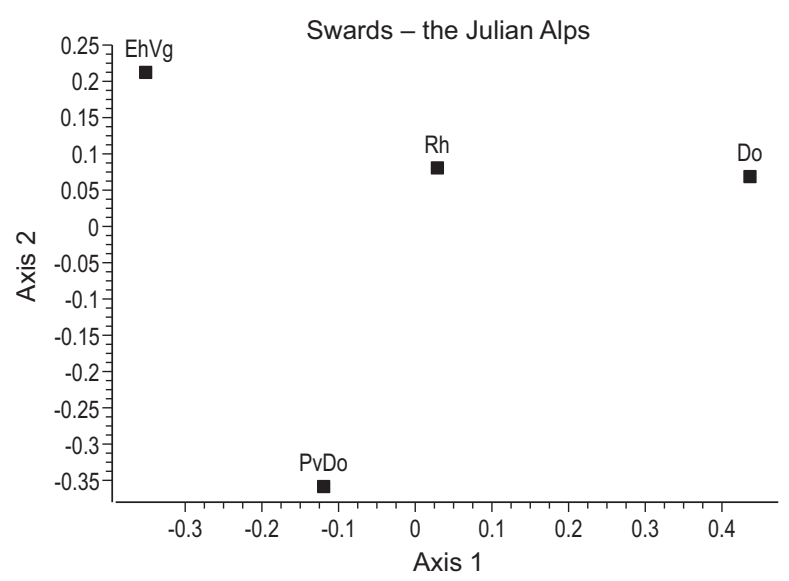

Figure 7: Two dimensional scatter-diagram of subalpinealpine swards and heaths (PvDo - Pulsatillo vernalis-Dryadetum, Do - Dryadetum octopetalae, Rh - Rhododendretum hirsuti, EhVg - Empetro-Vaccinietum gaultherioidis) - PCoA, similarity ratio.

Slika 7: Dvorazsežn ordinacijski diagram subalpinsko-alpinskih rušnatih trat in resav (PvDo - Pulsatillo vernalisDryadetum, Do - Dryadetum octopetalae, Rh - Rhododendretum hirsuti, EhVg - Empetro-Vaccinietum gaultherioidis) - PCoA, similarity ratio.

on pastures Ovčarija and Za Grivo, where Pulsatilla vernalis grows, are classified into a new association Pulsatillo vernalis-Dryadetum octopetalae ass. nova, which is classified into the alliance Ericion Rübel ex Grabherr, Greimler \& Mucina 1993 and order Rhododendro hirsuti-Ericetalia carneae Grabherr, Greimler \& Mucina 1993. The question whether this order should be included into the class LoiseleurioVaccinietea (as proposed in the Flora alpina - Theurillat in Aeschimann \& al. 2004 c: 310), or into the class Elyno-Seslerietea (Grabherr \& al. 1993) is left unanswered. According to the analysis of groups of diagnostic species (Table 4), priority in this case should be given to the class Elyno-Seslerietea. The diagnostic (differential) species of the new association are Dryas octopetala, Pulsatilla vernalis, Vaccinium vitis-idaea, Homogyne discolor, Juniperus alpina and Vaccinium gaultherioides. Each of them is diagnostic for a different phytosociological group and their collective growth indicates a quite unique site. The species Dryas octopetala indicates initial soil and the pioneer stage of development of the community, Pulsatilla vernalis, Vaccinium vitis-idaea and V. gaultherioides are indicative of a slow decomposition of organic matter and acid humus, Homogyne discolor indicates a site where the snow keeps for a long time and Juniperus alpina a syndynamic connection with a dwarf pine community. 
The relevés in Table 1 were compared with hierarchic classification and PCoA ordination method (Figures 8 to 10). In all the methods tested they united into two groups which are treated as two subassociations. Axis 1 in Figure 10 also indicates the temperature gradient, on the left are relevés from a slightly warmer rim and on the right are the relevés from a slightly colder point of the dolines.

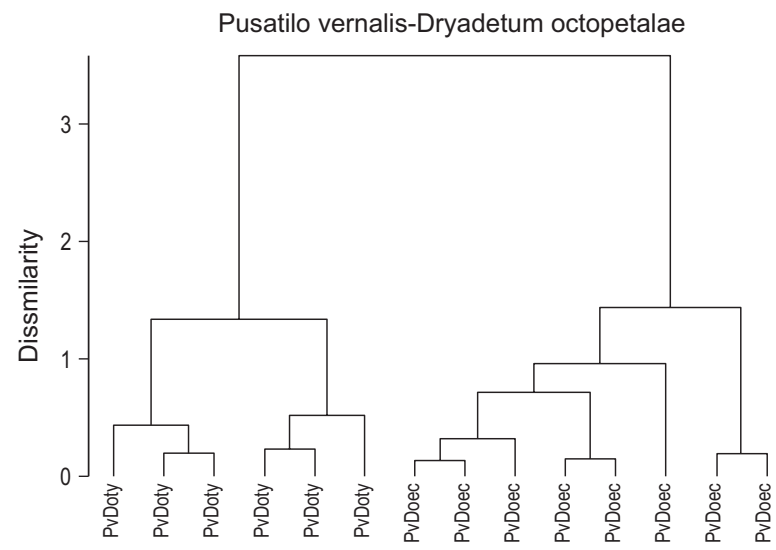

Figure 8: Dendrogram of the stands with Pulsatilla vernalis on the pasture Ovčarija and Za Grivo (MISSQ - similarity ratio); PvDoty - Pulsatillo vernalis-Dryadetum vaccinietosum, PvDoec - Pulsatillo vernalis-Dryadetum ericetosum carneae.

Slika 8: Dendrogram sestojev z vrsto Pulsatilla vernalis na pl. Ovčarija in Za Grivo (MISSQ - similarity ratio); PvDoty - Pulsatillo vernalis-Dryadetum vaccinietosum, PvDoec Pulsatillo vernalis-Dryadetum ericetosum carneae.

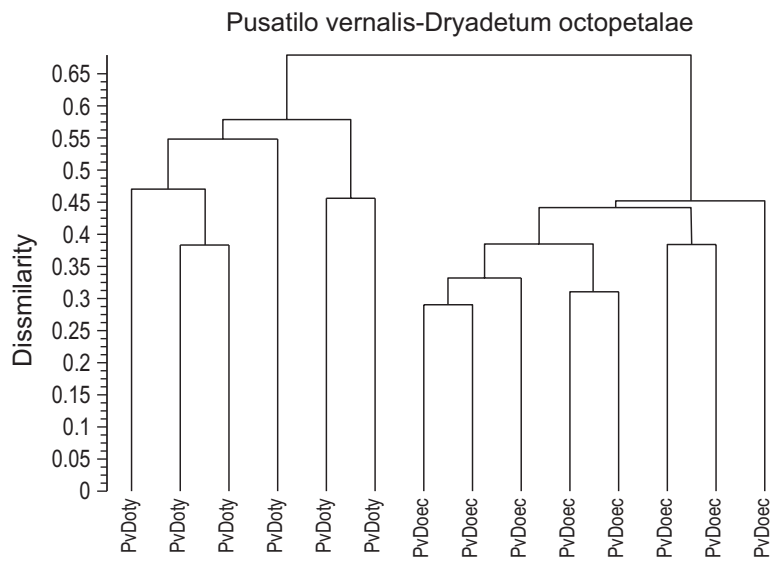

Figure 9: Dendrogram of the stands with Pulsatilla vernalis on the pasture Ovčarija and Za Grivo (UPGMA - similarity ratio); PvDoty - Pulsatillo vernalis-Dryadetum vaccinietosum, PvDoec - Pulsatillo vernalis-Dryadetum ericetosum carneae

Slika 9: Dendrogram sestojev z vrsto Pulsatilla vernalis na pl. Ovčarija in Za Grivo (UPGMA - similarity ratio); PvDoty - Pulsatillo vernalis-Dryadetum vaccinietosum, PvDoec - Pulsatillo vernalis-Dryadetum ericetosum carneae

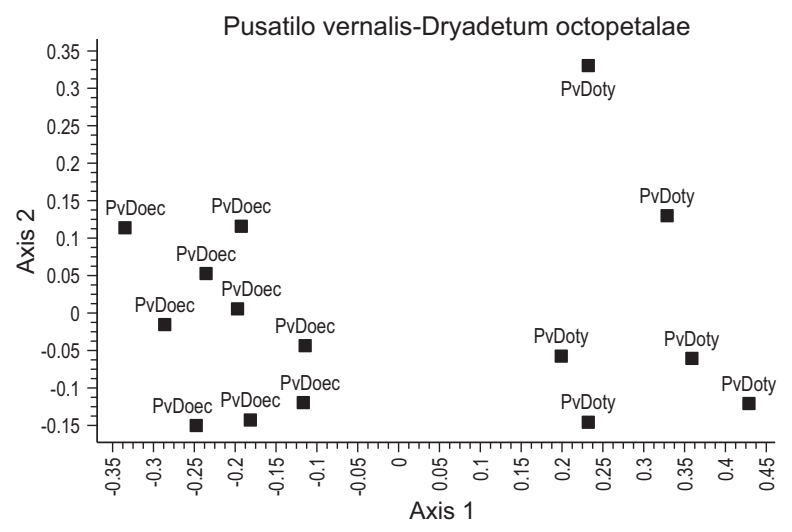

Figure 10: Two-dimensional scatter diagram of the stands with Pulsatilla vernalis on the pasture Ovčarija and Za Grivo (PCoA - similarity ratio); PvDoty - Pulsatillo vernalis-Dryadetum vaccinietosum, PvDoec - Pulsatillo vernalis-Dryadetum ericetosum carneae.

Slika 10: Dvorazsežni diagram sestojev z vrsto Pulsatilla vernalis na pl. Ovčarija in Za Grivo (PCoA - similarity ratio); PvDoty - Pulsatillo vernalis-Dryadetum vaccinietosum, PvDoec - Pulsatillo vernalis-Dryadetum ericetosum carneae.

The relevés on the pasture Ovčarija were made on the rim above the lowest point of the doline, i.e. on a little less frosty exposition in comparison with the relevés on Za Grivo, with a thinner layer of raw humus (the vegetation manifests a more obvious influence of calcareous, limestone bedrock). This is indicated above all by Erica carnea, Daphne striata and Rhodothamnus chamaecistus (the diagnostic species of the order Rhododendro hirsuti-Ericetalia carneae), as well as by Carex sempervirens and Senecio abrotanifolius. The species listed are the differential species of the subassociation Pulsatillo vernalisDryadetum octopetalae ericetosum carneae subass. nova. Its nomenclature type (holotypus) is relevé No. 9 in Table 1, which is also the nomenclature type (holotypus) of the new association. The relevés on Za Grivo were made in the frost hollow itself (although the Pulsatilla vernalis there can grow also on the rim of the doline, together with Erica carnea, so the stands of the subassociation-ericetosum carnea are preseneted also on locality Za Grivo), on acid soil (Table 6). They are classified into the new subassociation Pulsatillo vernalis-Dryadetum octopetalae vaccinietosum subass. nova. Characteristic for these stands is an abundant growth of three species from the order Vaccinium (V. vitis-idaea, V. gaultherioides and $V$. myrtillus), while the differential species of the subassociation are also Primula halleri, Salix retusa and S. alpina (which indicate a certain similarity with snow-bed communities). The nomencla- 
ture type (holotypus) of this subassociation is relevé No. 2 in Table 1. As regards the dilemma between the classes Loiseleurio-Vaccinietea and Elyno-Seslerietea it can be said that the relevés of the syntaxon Pulsatillo vernalis-Dryadetum octopetalae vaccinietosum are slightly more similar to the community Empetro-Vaccinietum gaultherioidis and are closer to the class Loiseleurio-Vaccinietea, while the relevés of the syntaxon Pulsatillo vernalis-Dryadetum octopetalae ericetosum carneae are a little more similar to the association Rhododendretum hirsuti and are closer to the class Elyno-Seslerietea.

\section{CONCLUSIONS}

Applying the standard Central-European method we phytosociologically studied the sites of Pulsatilla vernalis, a rare and protected species of Slovenian flora, in the frost hollows on the mountain pastures Ovčarija and Za Grivo (new locality!) in the Fužina pasturelands (the Triglav mountains, the Julian Alps). The humid montane climate with a thick snow cover in the cold part of the year and an explicit frost hollow site, confirmed by the measurements of the Slovenian meteorological forum, are the reasons for a slow decomposition of organic matter and development of the organogenic rendzina (folic leptosols) characterized by raw humus (Mor). On small surfaces on the rims of frost hollows developed a unique vegetation dominated by herbaceous perennials (hemicryptophytes), half-bushes and dwarf shrubs (chamaephytes). Such vegetation is actually characteristic of the Arctic regions, high mountains and deserts, i.e. for extreme life conditions. The species able to adapt to such circumstances are above all those with south-European montane distribution and arctic-alpine species. Regarding their phytosociological affiliation they belong above all to the class of subalpine-alpine swards and grasslands on calcareous bedrock Elyno-Seslerietea, the order of Alpine (montane) heaths on calcareous bedrock Rhododendro hirsuti-Ericetalia carneae, the class of subalpine-alpine swards on acid soil Juncetea trifidae (= Caricetea curvulae), the class of subalpine-alpine heaths Loiseleurio-Vaccinietea, to the alliance of naked-rush swards Oxytropido-Elynion and the order of snow-bed vegetation Arabidetalia caeruleae. The highest cover index ( $\mathrm{I}_{c}$, Lausi \& al. 1982) among them and the largest share of coverage $\left(\mathrm{D}_{\%}, \mathrm{Su}-\right.$ rina 2004, 2005) have Dryas octopetala, Vaccinium vitis-idaea and Pulsatilla vernalis. Three slightly similar communities have been described in the Julian Alps (the Krn mountains) so far: Dryadetum octopetalae, Rhododendretum hirsuti and Empetro-Vaccinietum gaultherioidis (Surina 2005). However, they are floristically clearly different from the community with Pulsatilla vernalis (Figures 4-7) and the latter is therefore classified into a new association Pulsatillo vernalis-Dryadetum octopetalae ass. nova, which is characterized (differentiated) by Pulsatilla vernalis, Dryas octopetala, Vaccinium vitis-idaea, V. gaultherioides, Homogyne discolor and Juniperus alpina. The new association is subdivided into two subassociations (Figures 8-10): -ericetosum carneae subass. nova on sites with a thinner layer of raw humus and a more explicit influence of calcareous bedrock (nomenclature type, holotypus, is relevé No. 9 in Table 1, which is also the nomenclature type, holotypus, of the new association, while the differential species are Erica carnea, Daphne striata, Rhodothamnus chamaecistus, Carex sempervirens and Senecio abrotanifolius) and -vaccinietosum on explicitly frost hollow sites with acid raw humus (nomenclature type, holotypus, is relevé No. 2 in Table 1, and the differential species are Vaccinium vitisidaea, V. gaultherioides - both on account of their abundance, V. myrtillus, Primula halleri, Salix retusa and S. alpina). The new association is classified into the alliance Ericion carneae, order Rhododendro hirsuti-Ericetalia carneae and class Elyno-Seslerietea. Because Pulsatilla vernalis is a rare and protected species of the Slovenian flora (Skoberne 2007: 9, T. Wraber 2007: 134) its localities on the pasture Ovčarija and Za Grivo deserve our undivided attention. Despite the fact that Slovenian Alps have been well researched the species may have been somewhat overlooked because of its early spring flowering (as soon as the snow thaws). With a more thorough examination of similar sites (frost hollows) elsewhere in the Fužinske planine, on Komna and similar high-Karst plateaus, new localities of this species may be found.

\section{POVZETEK}

\section{Nahajališča in rastišča vrste Pulsatilla vernalis $\mathbf{v}$ Julijskih Alpah}

V Fužinskih planinah, na pl. Ovčarija, 1660 m nm. v. (Triglavsko pogorje, Julijske Alpe, severozahodna Slovenija), je leta 2002 fotograf Marko Pogačnik odkril vijoličasto cvetočega kosmatinca, ki sta ga 
Ivan Veber in Peter Skoberne spoznala za vrsto Pulsatilla vernalis (Veber 2006). Spomladi (maja) in poleti (julija) 2007 smo si njegova nahajališča na pl. Ovčarija podrobno ogledali in odkrili še eno nahajališče v bližnji kotanji Za Grivo, na podobni nadmorski višini (1635-1650 m nm. v.) - sliki 1 in 2. To so doslej edina znana nahajališča te evropske montanske vrste, značilnice kisloljubnih subalpinsko-alpinskih travišč iz razreda Juncetea trifidi (= Caricetea curvulae) v Julijskih Alpah in v Sloveniji, zato smo jih podrobno fitocenološko preučili po standardni srednjeevropski metodi (Braun-Blanquet 1964) - tabela 1. Na pl. Ovčarija in Za Grivo vrsta Pulsatilla vernalis raste na obodu mraziščnih kotanj oz. prav v njihovem dnu, na triasnem apnencu. Potencialno naravna vegetacija teh kotanj je bilo najbrž ruševje (Rhododendro hirsuti-Pinetum prostratae), ki so ga v preteklosti izkrčili za potrebe planine. Ruševje še zdaj uspeva na robovih kotanj, višje na pobočjih tudi vrzelasto macesnovje (RhodothamnoLaricetum). Humidno gorsko podnebje $\mathrm{z}$ obilno snežno oddejo v hladnem delu leta in še posebej očitna, z meritvami Slovenskega meteorološkega foruma potrjena mraziščna lega (slika 3) sta vzrok za počasen razkroj organske snovi in razvoj organogene rendzine, za katero je značilen surov humus. Na obodih mraziščnih kotanj se je na majhnih površinah razvilo svojevrstno rastje, v katerem prevladujejo zelnate trajnice (hemikriptofiti) ter polgrmi in nizki grmiči (hamefiti) - tabela 2. Takšno rastje je sicer značilno za Arktiko, visokogorje in puščave, torej za skrajne življenjske razmere. Vrste, ki se jim lahko prilagodijo, so po svoji razširjenosti predvsem južnoevropske gorske $(31 \%)$ in arktično-alpinske (17\%) - tabela 3. Po svoji fitocenološki navezanosti pripadajo predvsem razredu subalpinsko-alpinskih travišč na karbonatni podlagi Elyno-Seslerietea, redu alpskih (gorskih) resav na karbonatni podlagi Rhododendro hirsutiEricetalia carneae, razredu subalpinsko-alpinskih travišč na kislih tleh Juncetea trifidae (= Caricetea curvulae), razredu subalpinsko-alpinskih resav Loiseleurio-Vaccinietea, zvezi rušnatih trat z elino Oxytropido-Elynion in redu rastja snežnih dolinic Arabidetalia caeruleae - tabela 4. Med njimi imajo največji indeks pokrovnosti $\left(\mathrm{I}_{c}\right.$, Lausi \& al. 1982) in največji delež pokrovnosti $\left(\mathrm{D}_{\%}\right.$, Surina 2004, 2005) vrste Dryas octopetala, Vaccinium vitis-idaea in Pulsatilla vernalis - tabela 1. V Julijskih Alpah, v Krnskem pogorju, je Surina (2005) ugotovil tri nekoliko podobne združbe: Dryadetum octopetalae, Rhododendretum hirsuti in Empetro-Vaccinietum gaultherioidis. Vse so floristično očitno precej različne od združbe, kjer raste vrsta Pulsatilla vernalis (slike 4-7). Zato to uvrščamo v novo asociacijo Pulsatillo vernalis-Dryadetum octopetalae ass. nova, ki jo označujejo (razlikujejo) vrste Pulsatilla vernalis, Dryas octopetala, Vaccinium vitis-idaea, V. gaultherioides, Homogyne discolor in Juniperus alpina. Novo asociacijo členimo na dve subasociaciji (slike 8-10): -ericetosum carneae subass. nova na rastiščih s tanjšo plastjo surovega humusa in bolj očitnim vplivom karbonatne matične podlage (nomenklaturni tip, holotypus, je fitocenološki popis št. $9 \mathrm{v}$ tabeli 1 , to je tudi nomenklaturni tip, holotypus, nove asociacije, razlikovalnice pa so vrste Erica carnea, Daphne striata, Rhodothamnus chamaecistus, Carex sempervirens in Senecio abrotanifolius) in -vaccinietosum na izrazito mraziščnih legah s kislim surovim humusom. Njen nomenklaturni tip, holotypus, je fitocenološki popis št. $2 \mathrm{v}$ tabeli 1 , razlikovalnice pa so vrste Vaccinium vitis-idaea, V. gaultherioides (obe zaradi svoje obilnosti), V. myrtillus, Primula halleri, Salix retusa in S. alpina. Novo asociacijo uvrščamo $\mathrm{v}$ zvezo Ericion carneae, $\mathrm{v}$ red Rhododendro hirsuti-Ericetalia carneae in v razred Elyno-Seslerietea. Ker je Pulsatilla vernalis redka in zavarovana vrsta slovenske flore (Skoberne 2007: 9, T. Wraber 2007: 134) zaslužijo njena nahajališča na pl. Ovčarija in Za Grivo vso našo pozornost. Mogoče je, da je bila ta vrsta zaradi zgodnjega cvetenja na začetku gorske pomladi (takoj ko skopni sneg) doslej kljub dobri botanični raziskanosti naših Alp nekoliko prezrta in morda bomo s podrobnim pregledom podobnih rastišč (mraziščnih kotanj) drugod v Fužinskih planinah, na Komni in na podobnih visokokraških planotah našli njena nova nahajališča.

\section{ACKNOWLEDGEMENTS}

The photographer Marko Pogačnik with his find was the key person in writing this paper. Brane Anderle cooperated in the flora inventory in the doline Za Grivo. Mihej Urbančič, B.Sc., kindly performed the soil description and Dr. Tinka Bačič helped by determining the taxon Luzula exspectata. Researchers of frost hollows from the Slovenian meteorological forum provided the valuable temperature data. Prof. Dr. Livio Poldini, Prof. Dr. Dmitar Lakušić and Dr. Snežana Vukojičić gave us a lot of useful information on the localities and sites of Pulsatilla vernalis. Prof. Dr. Paul Heiselmayer, Doc. Dr. Boštjan Surina and Prof. Dr. Vlado Matevski improved the text with valuable corrections. English translation by Andreja Šalamon Verbič. 


\section{REFERENCES}

Adler, W., Oswald, K., Fischer, R. \& al. 1994: Exkursionsflora von Österreich. Verlag Eugen Ulmer, Stuttgart, Wien, $1180 \mathrm{pp}$.

Aeschimann, D., Lauber, K., Moser, D. M. \& Theurillat, J.-P. 2004 a: Flora alpina. Bd. 1: Lycopodiaceae-Apiaceae. Haupt Verlag, Bern, Stuttgart, Wien, 1159 pp.

Aeschimann, D., Lauber, K., Moser, D. M. \& Theurillat, J.-P. 2004 b: Flora alpina. Bd. 2: Gentianac eae-Orchidaceae. Haupt Verlag, Bern, Stuttgart, Wien, 1188 pp.

Aeschimann, D., Lauber, K., Moser, D. M. \& Theurillat, J.-P. 2004 c: Flora alpina. Bd. 3: Register. Haupt Verlag, Bern, Stuttgart, Wien, 322 pp.

Amidžić, L. \& Panjković, B. 2003: Vaskularna flora. In: Amidžić, L., Janković, M. \& Jakšić, P. (eds.): Metohijske Prokletije. Prirodna i kulturna baština, Beograd, pp. 149-177.

Braun-Blanquet, J. 1964: Pflanzensoziologie. Grundzüge der Vegetationskunde. 3. Auflage. Springer, Wien - New York, 865 pp.

Buser, S. 1986: Tolmač listov Tolmin in Videm (Udine). Osnovna geološka karta SFRJ $1: 100$ 000. Zvezni geološki zavod, Beograd, 103 pp.

Buser, S. 1987: Osnovna geološka karta SFRJ. Tolmin in Videm 1: 100 000. Zvezni geološki zavod, Beograd.

Cevc, T. 1992: Bohinj in njegove planine. Didakta, Radovljica, $152 \mathrm{pp}$.

Diklić, N. 1992: Rod Pulsatilla Miller. In: Sarić, M. R. (ed.): Flora Srbije 1 (The Flora of Serbia 1). Srpska akademija nauka i umetnost (Serbian Academy of the Sciences and the Arts), Beograd, pp. 325-331.

Exner, A. 2007: Piceetalia Pawł 1928. In: Willner, W. \& Grabherr, G. (eds.): Die Wälder und Gebüsche Österreichs. Ein Bestimmungswerk mit Tabellen. 1. Textband. Spektrum Akademischer Verlag \& Elsevier, Heidelberg, pp. 184-208.

Frahm, J. P. \& Frey, W. 1992: Moosflora. 3. Aufl. UTB, Eugen Ulmer, Stuttgart, 522 pp.

Grabherr, G. 1993 a: Caricetea curvulae. In: Grabherr, G. \& Mucina, L. (eds.): Die Pflanzengesellschaften Österreichs, Teil II: Natürliche waldfreie Vegetation, Gustav Fischer Verlag, Jena, Stuttgart, New York, pp. 343-372.

Grabherr, G. 1993 b: Carici rupestris-Kobresietea bellardii. In: Grabherr, G. \& Mucina, L. (eds.): Die Pflanzengesellschaften Österreichs, Teil II: Natürliche waldfreie Vegetation, Gustav Fischer Verlag, Jena, Stuttgart, New York, pp. 373-381.
Grabherr, G. 1993 c: Loiseleurio-Vaccinietea. In: Grabherr, G. \& Mucina, L. (eds.): Die Pflanzengesellschaften Österreichs, Teil II: Natürliche waldfreie Vegetation, Gustav Fischer Verlag, Jena, Stuttgart, New York, pp. 447-467.

Grabherr, G., Greimler, J. \& Mucina, L. 1993: Seslerietea albicantis. In: Grabherr, G. \& Mucina L. (eds.): Die Pflanzengesellschaften Österreichs. Teil II: Natürliche waldfreie Vegetation, Gustav Fischer Verlag, Jena, Stuttgart, New York, pp. 402-446.

Hartl, H., Kniely, G., Leute, G., Niklfeld, H. \& Perko, M. 1992: Verbreitungsatlas der Farn- und Blütenpflanzen Kärntens. Naturwissensschaftlichen Verein für Kärnten, Klagenfurt, 451 pp.

IUSS Working Group WRB 2006: World reference base for soil resurces 2006. $2^{\text {nd }}$ edition. World Soil Resources Reports No. 103, FAO, Rome, 128 pp.

Krivošej, Z. \& Ranđelović, N. 1996 (1997): Prilog flori planine Đeravice (I). The University Thought. Publication in Natural Sciences 3 (2): 23-26.

Kunaver, J. 1985: Relief. In: Fabjan, I. (ed.): Triglavski narodni park. Vodnik. Triglavski narodni park, Bled, pp. 29-56.

Lausi, D., Gerdol, R. \& Piccoli, F. 1982: Dynamics of Ostrya carpinifolia woods in the Southern Alps (N-Italy). Vegetatio 48 (2): 123-131.

Maarel van der, E. 1979: Transformation of coverabundance values in phytosociology and its effects on community similarity. Vegetatio 39 (2): 97-114.

Martinčič, A. 1977: Prispevek k poznavanju ekologije mrazišč v Sloveniji: botanično-ekološka skica (Beitrag zur Kenntnis der Ökologie der Kältelöcher in Slowenien: botanisch-ökologische Skizze). Razprave 4. razreda SAZU 20 (5): 230-317.

Martinčič, A. 2003: Seznam listnatih mahov (Bryopsida) Slovenije. Hacquetia 2 (1): 91-166.

Martinčič, A., Wraber, T., Jogan, N., Podobnik, A., Turk, B., Vreš, B., Ravnik, V., Frajman, B., Strgulc Krajšek, S., Trčak, B., Bačič, T., Fischer, M. A., Eler, K. \& Surina, B. 2007: Mala flora Slovenije. Ključ za določanje praprotnic in semenk. Četrta, dopolnjena in spremenjena izdaja. Tehniška založba Slovenije, Ljubljana, 967 pp.

Mekinda - Majaron, T. 1995: Klimatografija Slovenije. Temperatura zraka 1961-1990. Hidrometeorološki zavod Republike Slovenije, Ljubljana, $356 \mathrm{pp}$.

Melik, A. 1950: Planine v Julijskih Alpah. Slovenska akademija znanosti in umetnosti. Razred za pri- 
rodoslovne in medicinske vede. Dela 1 , Ljubljana, 302 pp.

Micevski, K. 1978: Retki i nepoznati vidovi za florata na Makedonija. God. Zbor. Biološki fakultet Univerziteta u Skoplju 31: 151-163.

Micevski, K. 1985: Pulsatilla vernalis (L.) Mill. In: Micevski, K.: Flora na Republika Makedonija (The Flora of the Republic of Macedonia). Vol. 1, Book 1. Makedonska akademija na naukite i umetnostite, Skopje, pp. 111.

Mihelič, T. 1992: Julijske Alpe. Planinski vodnik. 4. popravljena izdaja. Planinska založba PZS, Ljubljana, 352 pp.

Niketić, M., Melovski, Lj. \& Tomović, G. 2007: Pulsatilla vernalis (L.) Mill. In: Vladimirov, V., Dane, F., Matevski, V. \& Tan, K. (eds.): New floristic records in the Balkans: 4. Phytologia Balcanica 13 (1): 107-122.

Nikolić, V., Sigunov, A. \& Diklić, N. 1986: Dopuna Flori SR Srbije novim podacima o rasprostranjenju biljnih vrsta: In: Sarić, M. (ed.): Flora SR Srbije 10 (The Flora of Serbia 10). Dodatak (2). Srpska akademija nauka i umetnosti, Beograd, pp. 257-336.

Novak, A. 1985: Planšarstvo in pašne planine na gorenjski strani TNP. In: Fabijan, I. (ed.): Triglavski narodni park. Vodnik. Triglavski narodni park, Bled, pp. 147-160.

Oberdorfer, E. 1983: Pflanzensoziologische Exkursionsflora. 5. Aufl. Eugen Ulmer, Stuttgart, 1015 pp.

Ogrin, D., 1996: Podnebni tipi v Sloveniji. Geografski vestnik 68: 39-56.

Ogrin, D., Ogrin, M. \& Sinjur, I. 2007: Temperaturne razmere v slovenskih mraziščih. Proteus 69 (5): 198-204.

Oriolo, G. 2001: Naked rush swards (OxytropidoElynion Br.-Bl. 1949) on the Alps and the Apennines and their syntaxonomical position. Fitosociologia 38 (1): 91-101.

Pignatti, S. 1982: Flora d' Italia. Vol. 1. Edagricole, Bologna, 790 pp.

Podani, J. 2001: SYN-TAX 2000. Computer Programs for Data Analysis in Ecology and Systematics. User's Manual, Budapest, 53 pp.

Poldini, L. 1991: Atlante corologico delle piante vascolari nel Friuli-Venezia Giulia. Inventario floristico regionale. Regione Autonomo FriuliVenezia Giulia \& Università di Trieste, Udine, 898 pp.

Poldini, L. (with collaboration of G. Oriolo \& M. Vidali), 2002: Nuovo Atlante corologico delle piante vascolari nel Friuli Venezia Giulia. Regio- ne Autonoma Friuli Venezia Giulia, Azienda Parchi e Foreste Regionali \& Università degli Studi di Trieste, Dipartimento di Biologia, Udine. 529 pp.

Poldini, L. \& Bressan, E. 2007: I boschi ad abete rosso ed abete bianco in Friuli (Italia nordorientale). Fitosociologia 44 (2): 15-54.

Rohlena, J. 1942: Conspectus Florae Montenegrinae. Preslia 20-21: 1-506.

Seliškar, T., Vreš, B. \& Seliškar, A. 2003: FloVegSi 2.0. Računalniški program za urejanje in analizo bioloških podatkov. Biološki inštitut ZRC SAZU, Ljubljana.

Sinjur, I. \& Ogrin, M. 2006: Rekorden mraz $-41,7$ st. C so letošnjega 25. januarja izmerili na Komni: kje so meje ohlajanja $\mathrm{v}$ naših mraziščih. Delo, 18. februar 2006, 48 (38): 20.

Sinjur, I., Ogrin, M. \& Ogrin, D. 2007: Na poti k mrazu. Gea 17 (1): 28-31.

Skoberne, P. 2007: Narava na dlani. Zavarovane rastline Slovenije. Žepni vodnik. Mladinska knjiga, Ljubljana, 116 pp.

Stefanović, V. 1986: Fitocenologija sa pregledom šumskih fitocenoza Jugoslavije. 2. izdanje. Svijetlost, Sarajevo, $269 \mathrm{pp}$.

Surina, B. 2004: The association Gentiano terglouensis-Caricetum firmae T. Wraber 1970 in the Krn Mountains (The Julian Alps). Annales, Series Historia Naturalis 14 (1): 99-112.

Surina, B. 2005: Subalpinska in alpinska vegetacija Krnskega pogorja v Julijskih Alpah. Scopolia 57: $1-122$.

Theurillat, J.-P., Aeschimann, D., Küpfer, P. \& Spichiger, R. 1995: The higher vegetation units of the Alps. Colloques Phytosociologiques 23 (Large area vegetation surveys - Bailleul 1994), J. Cramer, Berlin, Stuttgart, pp. 189-239.

Trinajstić, I. 1973: Rod Pulsatilla. In: Trinajstić, I. (ed.): Analitička flora Jugoslavije 1 (2). Inštitut za botaniku Sveučilišta u Zagrebu, Zagreb, pp. 285-292.

Urbančič, M., Simončič, P., Prus, T. \& Kutnar, L. 2005: Atlas gozdnih tal. Zveza gozdarskih društev Slovenije, Gozdarski vestnik \& Gozdarski inštitut Slovenije, Ljubljana, 100 pp.

Veber, I. 2006: Spomladanski kosmatinec. Proteus 68 (9-10): 456.

Vukojičić, S. 2008: Glacijalni relikti u orofitskoj flori Srbije, Crne Gore i Makedonije. Doktorska disertacija. Biološki fakultet. Univerzitet u Beogradu, 282 pp.

Wirth, V. 1995: Flechtenflora. 2. Auf. Verlag Eugen Ulmer, Stuttgart, $661 \mathrm{pp}$. 
Wraber, T. 1969: Nekatere nove ali redke vrste v flori Julijskih Alp (III). Varstvo narave 6: 73-84.

Wraber, T. 1983: Nekatere nove ali redke vrste v flori Julijskih Alp (V). Biološki vestnik 31 (2): 119-126.

Wraber, T. 1984: Planinec-botanik na Mangartu. Planinski vestnik 84 (9): 398-403.

Wraber, T. 1996: Združbe skalnih razpok, melišč, rečnih prodišč, snežnih dolinic, visokogorskih resav in travišč. In: Gregori, J. \& al. (eds.): Narava Slovenije, stanje in perspektive. Društvo ekologov Slovenije, Ljubljana, pp. 107-112.

Wraber, T. 2007: Ranunculaceae - zlatičevke. In: Martinčič, A. (ed.): Mala flora Slovenije. Ključ za določanje praprotnic in semenk. Četrta, dopolnjena in spremenjena izdaja. Tehniška založba Slovenije, Ljubljana, pp. 122-151.

Zupančič, B. 1995: Klimatografija Slovenije. Padavine 1961-1990. Hidrometeorološki zavod Republike Slovenije, Ljubljana, 366 pp.

Zupančič, M. 1999: Smrekovi gozdovi Slovenije (Spruce forests in Slovenia). Slovenska akademija znanosti in umetnosti. Razred za naravoslovne vede, Dela (Opera) 36: 1-212.

\section{APPENDIX}

List of syntaxa mentioned in the article with authors:

Adenostylo glabrae-Piceetum M. Wraber ex Zukrigl 1973 corr. Zupančič 1993 (= Homogyno sylvestrisPiceetum Exner in Poldini \& Bressan 2007) Arabidetalia caeruleae Rübel ex Nordhagen 1936 Asplenietea trichomanis Br.-Bl. in Meier \& Br.-Bl. 1934

Calluno-Ulicetea Br.-Bl. \& R. Tüxen ex Klika 1948

Caricetalia davallianae Br.-Bl. 1949

Carici rupestris-Kobresietea bellardii Ohba 1974
Caricion austroalpinae Sutter 1962

Caricion firmae Gams 1936

Dryadetum octopetalae Rübel 1911

Elyno-Seslerietea Br.-Bl. 1948

Empetro-Vaccinietum gaultherioidis Br.-Bl. in Br.-Bl. \& Jenny 1926 corr. Grabherr 1993

Ericion Rübel ex Grabherr, Greimler \& Mucina 1993

Festuco-Brometea Br.-Bl. \& Tüxen 1943

Juncetea trifidi Hadač 1946 (= Caricetea curvulae Braun-Blanquet 1948)

Juniperion nanae Br.-Bl. in Br.-Bl., Sissingh \& Vlieger 1939

Loiseleurio-Vaccinietea Eggler ex Schubert 1948

Molinio-Arrhenatheretea R. Tüxen 1937 em. R. Tüxen 1970

Mulgedio-Aconitetea Hadač \& Klika in Klika 1948

Onobrychido-Seslerietalia Ht. 1949

Oxytropido-Elynion Br.-B1. 1949

Poo alpinae-Trisetalia Ellmauer \& Mucina 1993

Rhododendro hirsuti-Ericetalia carneae Grabherr, Greimler \& Mucina 1993

Rhododendro hirsuti-Pinetum prostratae Zöttl 1951

Rhododendretum hirsuti Lüdi 1921

Rhodothamno-Laricetum deciduae Willner \& Zukrigl 1999

Seslerietalia comosae Simon 1957

Seslerietalia variae Br.-Bl.in Br.-Bl. \& Jenny 1926

Sieversio-Nardetum strictae Lüdi 1948

Thlaspietea rotundifolii Br.-Bl. in Br.-Bl. \& Jenny 1926

Vaccinio-Piceetea Br.-Bl. 1939 emend. Zupančič (1976) 2000

\section{ABBREVIATIONS - OKRAJŠAVE}

\section{Parent material (Geološka podlaga)}

A - limestone - apnenec

Soil types (Talni tipi)

FoL - Folic Leptosols - organogena rendzina 


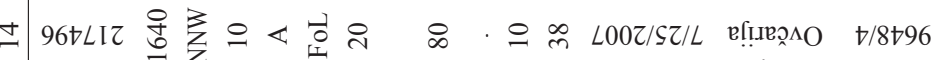

$\cong$

$\simeq$

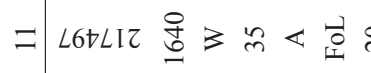

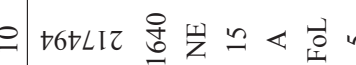

a

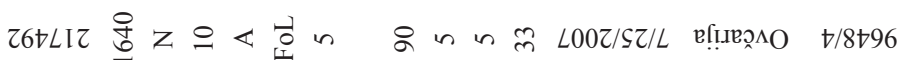
Id

$\infty$

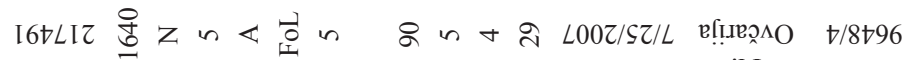

'Id

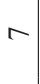

6

in

$+$

$+\operatorname{IttL}$

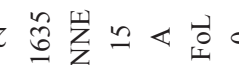

$m$ stth

$\sim$

V LttLIZ 导蛋的《宫

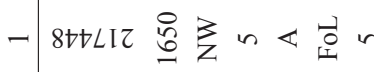

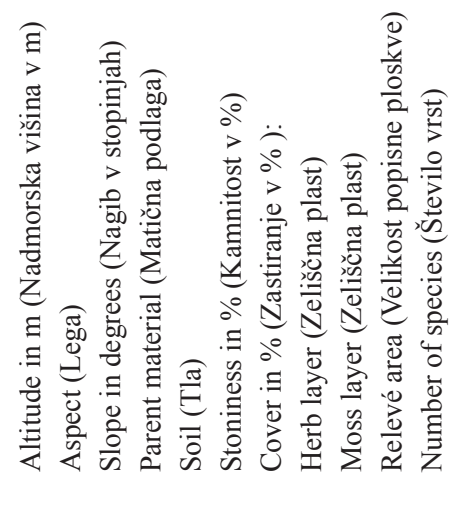

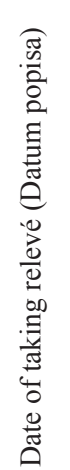

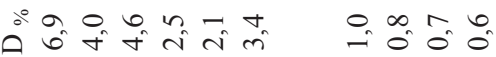

$$
\begin{aligned}
& \text { - ठठ }
\end{aligned}
$$

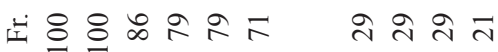

$$
\begin{aligned}
& \Xi \pm \Xi コ=0 \quad \forall+\sigma m
\end{aligned}
$$

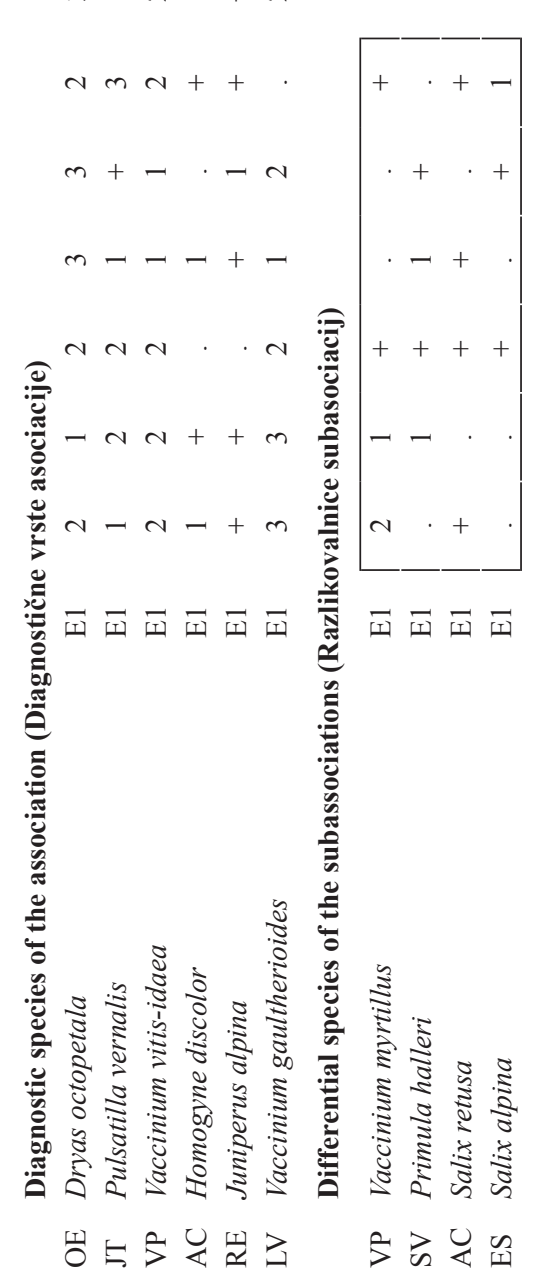




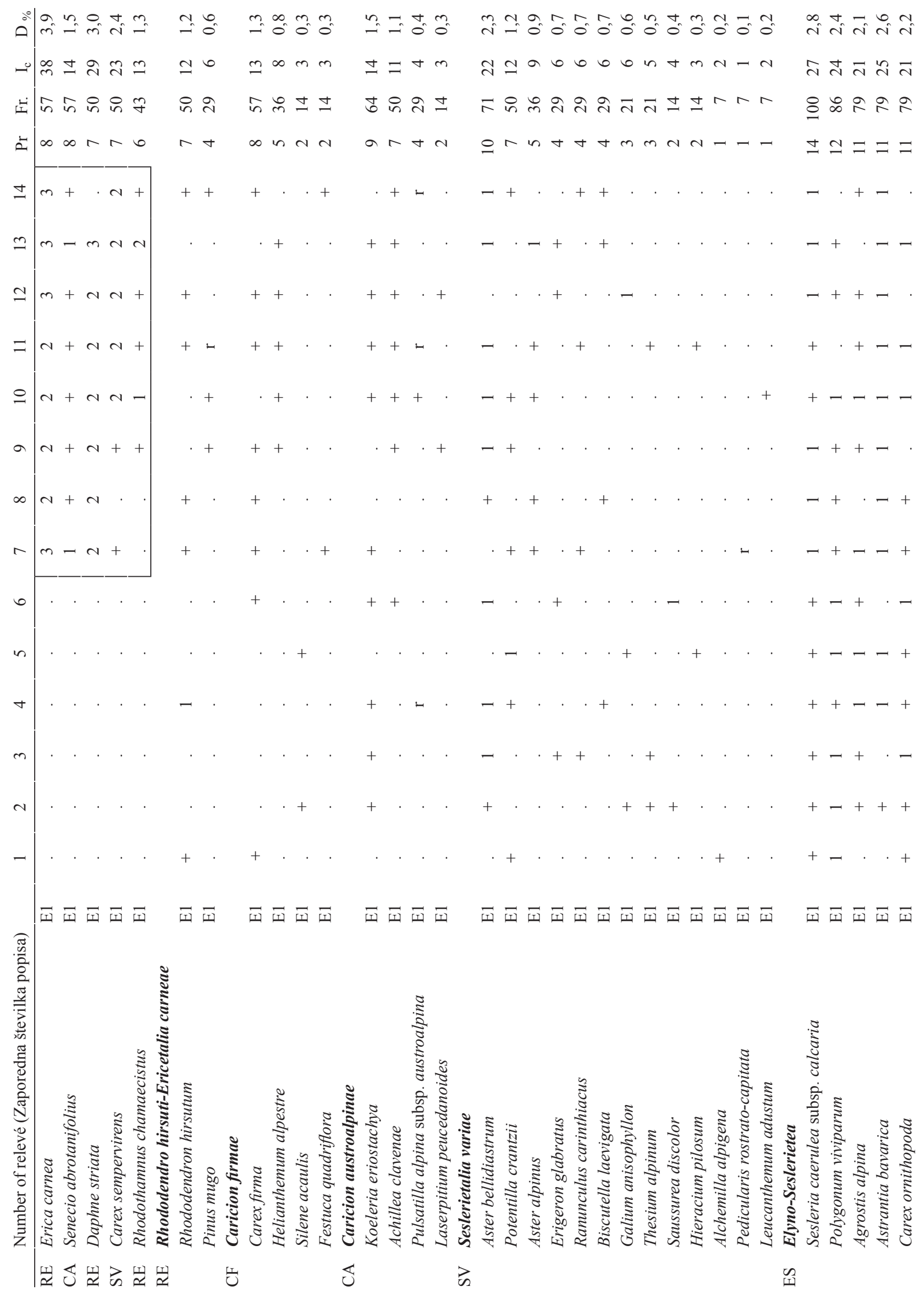




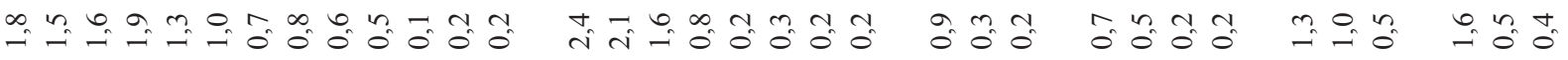

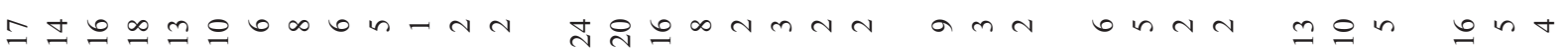

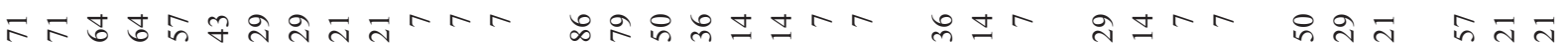
으의 0 t+mm-
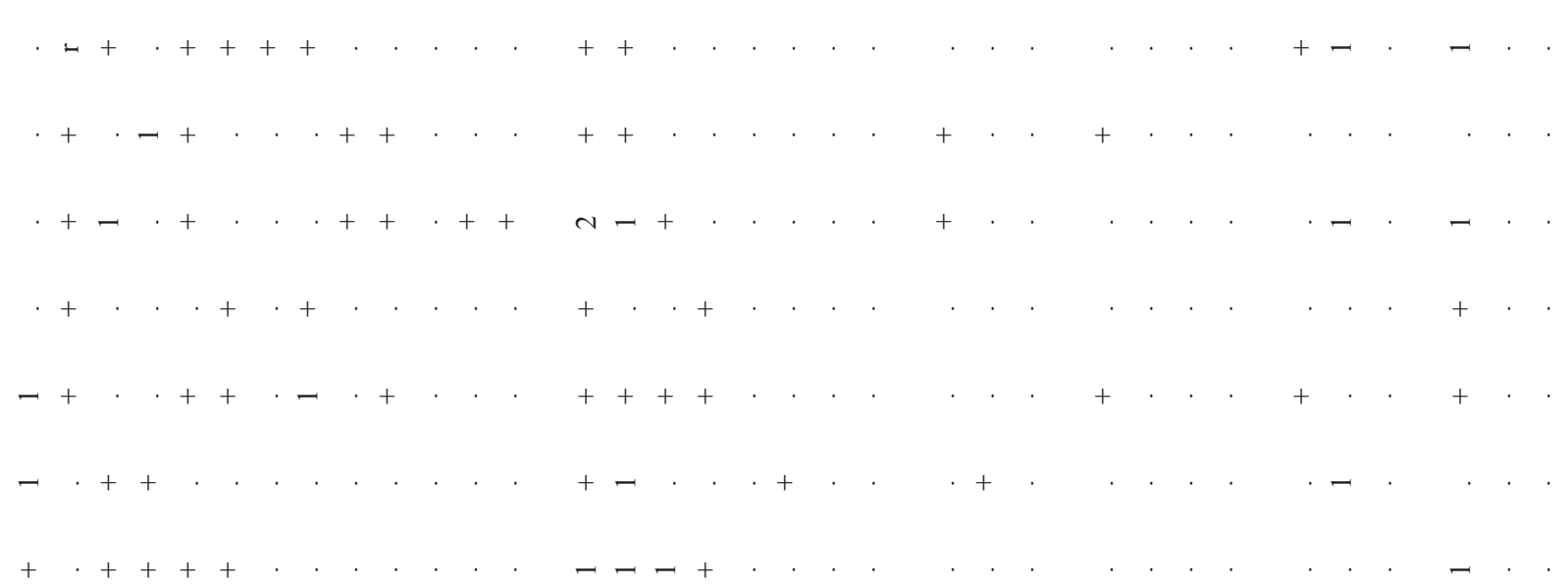

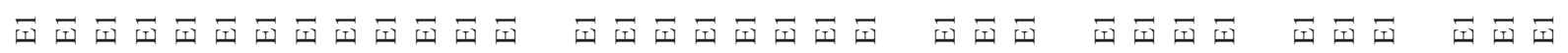
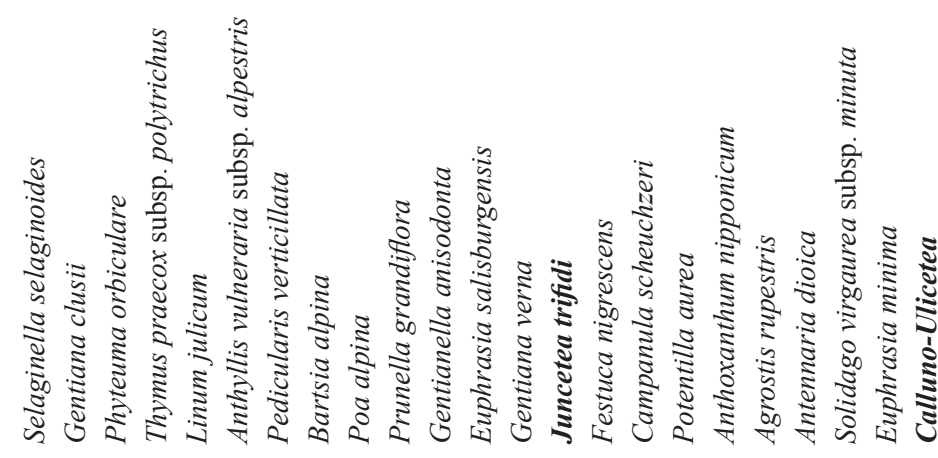

巨

$?$

땅

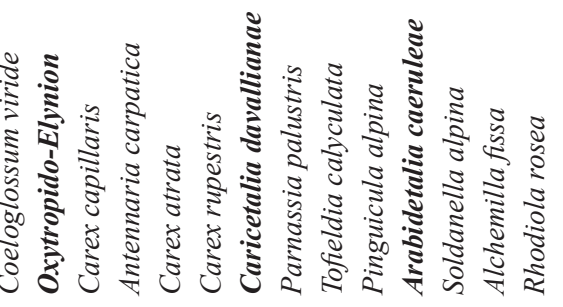

ठ ४ 


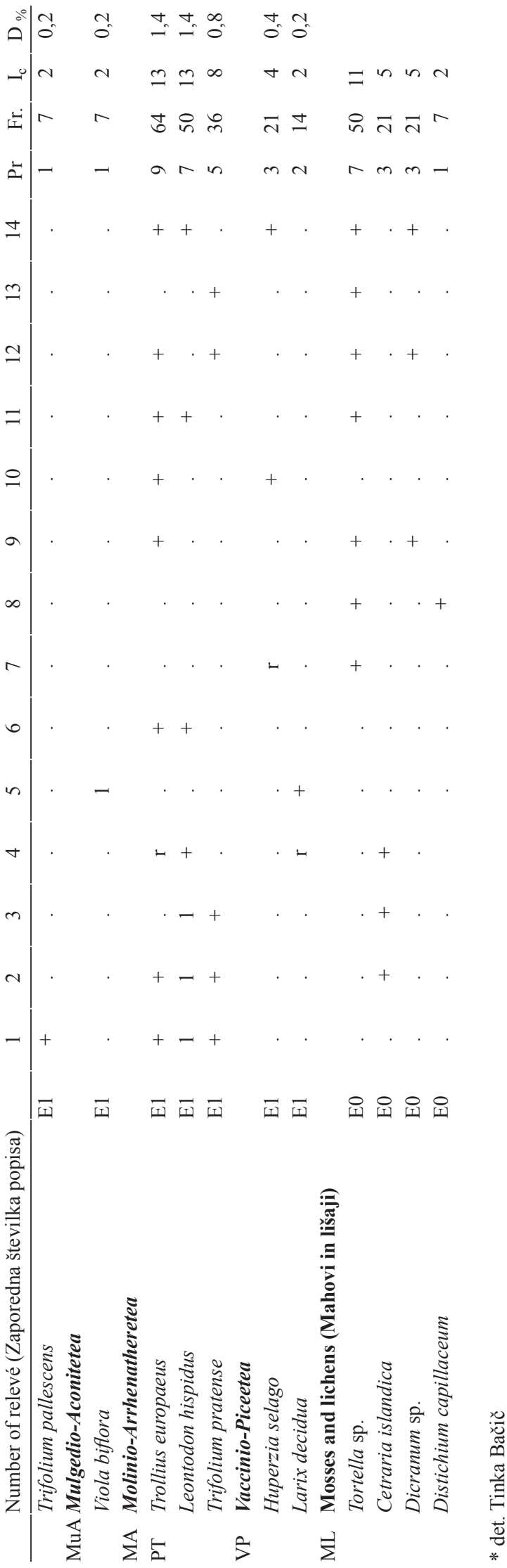




\begin{tabular}{|c|c|c|c|c|c|c|}
\hline & \multicolumn{2}{|l|}{ Succesive number of relevé (Zaporedna številka popisa) } & \multirow{2}{*}{$\begin{array}{c}1 \\
29\end{array}$} & \multirow{2}{*}{2} & \multirow{2}{*}{3} & \multirow{2}{*}{$\begin{array}{c}4 \\
33\end{array}$} \\
\hline & Erigeron glabratus & E1 & & & & \\
\hline & Ranunculus carinthiacus & E1 & 29 & . & 43 & . \\
\hline & Biscutella laevigata & E1 & 29 & 17 & 43 & . \\
\hline & Galium anisophyllon & E1 & 21 & 33 & 29 & 33 \\
\hline & Thesium alpinum & E1 & 21 & . & . & . \\
\hline & Saussurea discolor & E1 & 14 & . & . & . \\
\hline & Hieracium pilosum & E1 & 14 & . & . & . \\
\hline & Alchemilla alpigena & E1 & 7 & 17 & 14 & . \\
\hline & Pedicularis rostrato-capitata & E1 & 7 & . & 43 & 67 \\
\hline & Leucanthemum adustum & E1 & 7 & . & . & . \\
\hline & Geranium argenteum & E1 & . & 17 & 14 & 33 \\
\hline \multirow[t]{31}{*}{ ES } & Elyno-Seslerietea & & & & & \\
\hline & Sesleria caerulea subsp. calcaria & E1 & 100 & 83 & 86 & 100 \\
\hline & Polygonum viviparum & E1 & 86 & 100 & 59 & 100 \\
\hline & Agrostis alpina & E1 & 79 & . & . & . \\
\hline & Astrantia bavarica & E1 & 79 & 17 & 71 & 67 \\
\hline & Carex ornithopoda & E1 & 79 & . & 29 & . \\
\hline & Selaginella selaginoides & E1 & 71 & 17 & 86 & 100 \\
\hline & Gentiana clusii & E1 & 71 & 33 & 57 & 67 \\
\hline & Phyteuma orbiculare & E1 & 64 & 17 & . & . \\
\hline & Thymus praecox subsp. polytrichus & E1 & 64 & 17 & 14 & 67 \\
\hline & Linum julicum & E1 & 57 & . & 43 & . \\
\hline & Anthyllis vulneraria subsp. alpestris & E1 & 43 & 17 & 14 & 33 \\
\hline & Pedicularis verticillata & E1 & 29 & . & 43 & 33 \\
\hline & Bartsia alpina & E1 & 29 & . & 57 & 33 \\
\hline & Poa alpina & E1 & 21 & . & . & 67 \\
\hline & Prunella grandiflora & E1 & 21 & . & . & . \\
\hline & Gentianella anisodonta & E1 & 7 & 17 & . & 33 \\
\hline & Euphrasia salisburgensis & E1 & 7 & 17 & . & . \\
\hline & Gentiana verna & E1 & 7 & . & . & . \\
\hline & Heliosperma alpestre & E1 & . & 17 & 53 & . \\
\hline & Leontopodium alpinum & E1 & . & 17 & . & . \\
\hline & Arabis vochinensis & E1 & . & 17 & . & . \\
\hline & Cerastium strictum & E1 & . & 17 & . & . \\
\hline & Juncus monanthos & E1 & . & . & 57 & 67 \\
\hline & Carex ferruginea & E1 & . & . & 29 & . \\
\hline & Hieracium villosum & E1 & . & . & 29 & 67 \\
\hline & Helianthemum nummularium subsp. grandiflorum & E1 & . & . & 14 & 33 \\
\hline & Anemone narcissiflora & E1 & . & . & 14 & . \\
\hline & Phleum rhaeticum & E1 & . & . & 14 & . \\
\hline & Hedysarum hedysaroides & E1 & . & . & 14 & 100 \\
\hline & Euphrasia picta & E1 & . & . & . & 67 \\
\hline \multirow[t]{9}{*}{ JT } & Juncetea trifidi & & & & & \\
\hline & Festuca nigrescens & E1 & 86 & . & 14 & . \\
\hline & Campanula scheuchzeri & E1 & 79 & 17 & 29 & 67 \\
\hline & Potentilla aurea & E1 & 50 & . & . & . \\
\hline & Anthoxanthum nipponicum & E1 & 36 & . & 14 & . \\
\hline & Agrostis rupestris & E1 & 14 & . & . & 33 \\
\hline & Antennaria dioica & E1 & 14 & . & . & . \\
\hline & Solidago virgaurea subsp. minuta & E1 & 7 & 17 & 14 & . \\
\hline & Euphrasia minima & E1 & 7 & . & . & . \\
\hline
\end{tabular}


Succesive number of relevé (Zaporedna številka popisa)

Coeloglossum viride

OE Oxytropido-Elynion

Carex capillaris

Antennaria carpatica

Carex atrata

Carex rupestris

Arctospahylos alpina

Gentiana nivalis

RE Rhododendro hirsuti-Ericetalia carneae

Pinus mugo

Sorbus chamaemespilus

CD Caricetalia davallianae

Parnassia palustris

Tofieldia calyculata

Pinguicula alpina

AC Arabidetalia caeruleae

Soldanella alpina

Alchemilla fissa

Rhodiola rosea

Trifolium pallescens

Soldanella minima

Saxifraga aizoides

Salix serpyllifolia

Festuca nitida

Doronicum glaciale

TR Thlaspietea rotundifolii

Festuca laxa

Ranunculus traunfellneri

Aquilegia eniseleana

Cerastium carinthiacum

Moehringia ciliata

Rumex scutatus

Soldanella minima

Thlaspi kerneri

Cerastium subtriflorum

Armeria alpina

Athamnatha cretensis

Polystichum lonchitis

Gymnocarpium robertianum

Aconitum lycoctonum subsp. ranunculifolium

AT Asplenietea trichomanis

Valeriana saxatilis

Saxifraga crustata

Asplenium viride

Carex brachystachys

Primula auricula

Cystopetris regia
1

E1

E1

E1

2

3

4

E1

E1

E1

E1

E1

E1

E1

E1

29

17

14

7

29

67

29

14

7

7

.

El

E1

E1

E1

E1

E1

E1

E1

E1

E1

E1

E1

E1

E1

E1

E1

E1

E1

E1

E1

E1

E1

E1

E1

E1

E1

E1

50
29
21

21

57

21

21

7

.

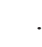

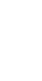

.

67

17

14

33

17

57

100

67

33

29

14

57

33

50

17

78

43

33

17

14

33

14

14

14

29

14

.

.

14

14

29

33

17

17

17

17

17

17

17

67

33

E1

E1

50

100

33

E1

17

17

.

43

29

14

14 
Succesive number of relevé (Zaporedna številka popisa)

1

2

3

4

MuA Mulgedio-Aconitetea

Viola biflora

E1

71

33

Salix waldsteiniana

E1

43

Geranium sylvaticim

E1

29

Veratrum album

E1

29

Alnus viridis

E1

14

Salix appendiculata

E1

14

MA Molinio-Arrhenatheretea

PT Trollius europaeus

Leontodon hispidus

E1

E1

14

33

Trifolium pratense

E1

Veronica chamaedrys

E1

Potentilla reptans

E1

Trifolium repens

E1

Ranunculus nemorosus

E1

64

50

.

14

14

14

14

VP Vaccinio-Piceetea

Huperzia selago

E1

14

Larix decidua

Pyrola roitundifolia

E1

14

14

E1

43

33

Homogyne alpina

E1

Picea abies

Clematis alpina

Luzula luzuloides

E1

29

29

14

Rosa pendulina

Lonicera caerulea

Lycopodium annotinum

E1

E1

E1

E1

E1

Maianthemum bifolium

E1

Saxifraga cuneifolia

E1

O Other species (Druge vrste)

Festuca sp.

Laserpitium siler

E1

E1

E1

Libanotis sibirica subsp. montana

E1

Sorbus aucuparia

E1

14

14

14

14

Alchemilla fallax

E0

E0

E0

E0

E0

E0

E0

Tortella sp. (inc. T. tortuosa)

Distichium capillaceum

Cladonia pyxidata

Cetraria nivalis

Cladonia furcata

Dicranum scoparium

PvDo - Pulsatillo vernalis-Dryadetum octopetalae

Do - Dryadetum octopetalae

$\mathrm{Rh}-$ Rhododendretum hirsuti

EhVg - Empetro-Vaccinietum gaultherioidis 
Table 6: WRB soil unit on the profile Za Grivo: Folic Leptosol (Urbančič 2008, in litt.).

Tabela 6: WRB talna enota na profilu Za Grivo: organogena rendzina - folični leptosol (Urbančič 2008, in litt.).

\begin{tabular}{cccl}
\hline $\begin{array}{c}\text { Location } \\
\text { Kraj }\end{array}$ & $\begin{array}{c}\text { Layer } \\
\text { Plast }\end{array}$ & $\begin{array}{c}\text { Depth }(\mathrm{cm}) \\
\text { Globina }\end{array}$ & \multicolumn{1}{c}{$\begin{array}{c}\text { Layer description } \\
\text { Opis plasti }\end{array}$} \\
\hline Za Grivo & $\mathrm{O}_{\mathrm{l}, \mathrm{f}}$ & $13-3$ & $\begin{array}{l}\text { Softy, felt, linked with many fine roots, dry, black to very dark brown (10 YR 1-2/2). } \\
\text { Mehka, polstena, povezana in prepletena s številnimi tankimi koreninami, suha, črna do } \\
\text { zelo temno rjava }(10 \text { YR 1-2/2). }\end{array}$ \\
Za Grivo & $\mathrm{O}_{\mathrm{h}} \mathrm{C}$ & $3-0$ & $\begin{array}{l}\text { Non-coherent to very friable consistence, dusty to very fine granular structure, abundant } \\
\text { rock fragments of angular dolomite gravel, dry, very dark brown }(10 \mathrm{YR} 2 / 2) . \\
\text { Sipke do lahko drobljive konsistence, prašnate do drobno zrnaste strukture, skelet } \\
\text { sestavlja ostrotrobi dolomitni drobir, suha, zelo temno rjava (10 YR 2/2) }\end{array}$ \\
\hline
\end{tabular}

Depths (heights) of layers, $\mathrm{pH}$ values, measured in water $\left(\mathrm{H}_{2} \mathrm{O}\right)$, contents of organic matter (humus), organic carbon (Corg) and total nitrogen $(\mathrm{N})$, ratio between organic carbon and total nitrogen $\left(\mathrm{C}_{\mathrm{org}} / \mathrm{N}\right)$. Globine (oz. višine) plasti, vrednosti pH, merjene v vodi $\left(\mathrm{H}_{2} \mathrm{O}\right)$, vsebnosti organske snovi (humusa), organskega ogljika (Corg) in celokupnega dušika $(N)$ ter razmerja med organskim ogljikom in celokupnim dušikom $\left(C_{\text {org }} / N\right)$.

\begin{tabular}{lcccccc}
\hline Layer & Depth $(\mathrm{cm})$ & $\mathbf{p H}\left(\mathrm{H}_{2} \mathrm{O}\right)$ & Humus $(\%)$ & Corg $(\%)$ & $\mathbf{N}(\%)$ & Corg/N $(\%)$ \\
\hline $\mathrm{O}_{\mathrm{l}, \mathrm{f}}$ & $13-3$ & 6,38 & 50,25 & 29,15 & 1,99 & 14,7 \\
$\mathrm{O}_{\mathrm{h}} \mathrm{C}$ & $3-0$ & 7,20 & 46,29 & 26,65 & 2,10 & 12,8 \\
\hline
\end{tabular}

